\title{
Influence of Business Characteristics on Microcredit Default in Kenya: a Comparative Analysis of Microfinance Institutions and Financial Intermediaries
}

\author{
Muturi Phyllis Muthoni ${ }^{1}$, Prof. Lewa, Peter Mutuku ${ }^{2}$, Dr. Riro, G. Kamau ${ }^{3}$ \\ ${ }^{I}$ Department of Business Administration and Management, School of Graduate Studies and Research, Dedan \\ Kimathi University of Technology, P.O Box 657-10100-Nyeri, Kenya \\ ${ }^{2}$ Chandaria School of Business United States International University-Africa, P.O Box 14634-00800, Kenya \\ ${ }^{3}$ School of Business, Dedan Kimathi University of Technology, Kenya, P.O Box 657-10100-Nyeri, Kenya
}

\begin{abstract}
This study sought to investigate causes of loan default within MFIs and Financial Intermediaries (FIs) in Kenya. The specific objective addressed was to evaluate the influence of business characteristics on loan default in MFIs and FIs. A target population of 48 MFIs institutions and 76 Financial Institutions was used. A multistage sampling procedure and a sample of 48 MFIs and 48 FIs were selected. Random sampling was used to select the respondents since each participant had an equal opportunity to be selected. Primary data was collected by use of a questionnaire and analyzed by quantitative methods by use of SPSS; Version 21. Descriptive statistics and inferential statistics were employed to make generalizations. Data was presented in form of frequency tables, bar charts and pie charts for easy interpretation of results. A multiple regression model and Pearson correlation were used to establish relationships among the variables. The findings of the study indicated business characteristics were significant among MFIs and FIs but with some differences in the parameters measured .The findings are of significance to policy makers, MFIs, FIs, small businesses, universities and the general public as a source of knowledge for future reference.
\end{abstract}

Key Terms: Loan Default, Microcredit, Portfolio at Risk (PAR), Microfinance Institutions (MFIs), Financial Intermediaries (FIs)

\section{Introduction}

Microcredit is an important strategy being used to reduce poverty among many countries across the globe. The world has over 10,000 Microfinance Institutions (MFIs) that serve 150-200 million clients (Etzensperger, 2014). Ruben (2007) defines it as a 'grant loan to the poorest of the poor without requiring collateral' with an assumption that the beneficiaries have the survival skills that facilitate for credit worthiness. Sinha (1998) as sighted by Wrenn (2005) gives a distinction between microcredit and microfinance and states that 'credit refers to small loans, where microfinance is used where the small loans are supplemented with other financial services such as insurance and savings. Microcredit, therefore, is small loans provided to low income individuals without collateral and includes other financial services.

Microcredit brings about interaction between the lenders and the borrowers for the purpose of starting and developing micro enterprises that benefit individuals and the community in fighting poverty (Buss, 2005). However there is a widespread global concern over the countries that offer microcredit funds. Micro credit though has a positive effect on improving peoples' livelihoods in many parts of the world, has experienced several hardships over the years. Default is a major concern in many countries in the world. Pachico (2009) highlights a numbers of cases that have been greatly affected for instance; the microfinance sector in Nicaragua in 2009 - 2010 suffered major crisis as a result of both financial downturn and the domestic No Pago (No payment) movement that was fuelled by political activists. The portfolio at risk in these MFIs was at 19 percent despite many write offs while the No Pago group advocated for a moratorium law that allowed debtors a 10 year amortization period with a very low interest rate (less than 8 percent). This greatly reduced the total portfolio granted by MFIs to the poor in Nicaragua. Similarly Kolar Microfinance in 2009 found itself in a similar crisis on delinquency as a result of multiple borrowing by clients facilitated by 'overheated lending environment created by competition amongst the many registered MFIs and unknown number of unregistered lenders'.

A similar crisis was experienced from Andhra Pradesh (India) in 2010 where a number of borrowers committed suicide over indebtedness as a result of rising debt stress among thousands of clients which led to high default rates and the government had to step in and regulate the MFI sector. Likewise Pakistan in 2010 experienced difficulties in loan recovery in the sector after heavy monsoon rains caused havoc in the country that resulted in people losing property, raw materials, tools and work spaces which was affected means of livelihood and experienced difficulties in meeting their loan obligations. In a similar fashion, Bosnia and Herzegovina microfinance sector experienced a rapid rate of growth from $2006-2008$, but later suffered high 
indebtedness among the borrowers due to global financial crisis caused by competition, advanced loans given without following the laid down procedures (increasing maximum loan amounts and widening loan purposes and introducing new products). These actions eventually led to 'high levels of cross-and over-indebtness among MFIs to clients.' In due time the loan arrears rose from 1 percent to 6 percent as a result of low remittances over a period of 3 years.

Globally many countries have come up with microcredit initiatives to start small businesses especially to empower women and the youth. Globally, youth enterprise fund is a widely used initiative by many governments to promote youth employment and a key driver to the economic growth. For example, the Royal bank of Scotland came up with support services that helped the youth to access funds, to do mentorship and networking program and startup capital for businesses. Similarly, the Canadian Youth Business Foundation established in 1996 was meant to design youth business loan program specifically tailor made for the unemployed and underemployed (Karlan \& Morduch, 2009). In South Africa, a program called Umsobomvu Youth Fund has gone a long way in alleviating poverty and unemployment with a nationwide support (Million, Nyikal \& Wania, 2012). However the fund faced numerous challenges especially in monitoring and evaluation (ibid). The same challenges were experienced in Uganda's government programs on the number of loans disbursed and very little attention given over the effectiveness of those loans borrowed by entrepreneurs (ibid).

The fiscal health of MFI sector in Sub Sahara Africa (SSA) is a cause of concern due to the increased portfolio at risk (MIX, 2010). The region records a Portfolio at Risk (PAR 30 ) greater than 5 percent, coupled by poor reporting, poor control systems, poor information systems and poor credit management (ibid). Despite the high potential of MFIs in Africa serious and closely related problems in microcredit debt payment have been noted (Buss, 2005). As a result most MFIs are likely to have unreliable financial and portfolio information in addition to a poorly equipped system in managing their credit portfolio or protecting customers' savings (CGAP, 2013). Most of these MFIs in SSA, the financial performance recorded showed high outstanding loans, high transaction costs and rising managerial costs (ibid). Ethiopia has 27 MFIs registered by National Bank of Ethiopia and massive default has been reported among small-scale holders which threatened Development Bank of Ethiopia until provision of inputs for credit by government was eventually stopped (Sileshi et al., 2012). According to Sileshi et al., (2012), loan default in Ethiopia is said to be a "tragedy as it leads to system failure in implementing appropriate lending strategies and credible credit policies".

The MFIs provide microcredit through group lending to the rural smallholders to narrow the gap between the demand and supply of credit (CBE, 2010). In Ghana, MFIs provide financial assistance to cooperative groups organized by farmers since groups have common goals and interests (Ayogyam et al. 2013). For the last three decades, these MFIs have been successful in granting loans but the trend has been worrying due to high default rate (ibid). Udoh (2008) observed that in Nigeria, 75 percent of government sponsored loans disbursed by Akwa Ibon State Agricultural Loan Board to farmers, 59 percent were loan defaulters. In Tanzania most rural SACCOs suffer from 'weak internal control systems and high non-performing loans because of ineffective loans management' (Maghimbi, 2010 and Bibi, 2006).

The Government of Kenya has put a lot of emphasis on accessibility and suitability flow of financial services to the low income earners in order to alleviate poverty (Murathe \& Weda, 2015). The government of Kenya has introduced various support initiatives for provision of credit to Micro and Small Enterprises (MSEs). These initiatives include provision of Public Entrepreneurial Funds (PEFs) which include; Women Enterprise Funds (WEF), Youth Enterprise Development Fund (YEF), Agricultural Finance Corporation, Kenya Industrial Estates (KIE) Fund and Uwezo Fund. These funds are disbursed by some Financial Intermediaries (FIs) partnering with the government. The key objectives are to; improve competition of MSEs, promote socialeconomic development, reduce poverty among entrepreneurs, increase financial accessibility, productivity and innovation (Gitau and Wanyoike, 2014). The funds are disbursed to promote economic empowerment among youth and women. It involves mobilization of poor or disadvantaged sections of the population by increasing accessibility of resources and opening opportunities for income generation (SLE, 2010). Microcredit is therefore a tool that enhances economic development to the poor in the society.

Kenya is rated the best in Africa and also the second best in provision of a conducive business environment for MFIs and the top ten in the world (EIU, 2010). Kenya's borrower's rate is rated the second largest (Mix and CGAP, 2010). However, the case of default is still raising concern in the MFIs and FIs sectors. The default rate among MFIs' sector is relatively higher compared to commercial banks with default rates ranging from 10\% -20\% while commercial banks have a less than 5\% default rate (Kiraka et al., 2013). According to Kiraka et al. (2013), the constituency women enterprise recorded 20-30\% default rate in 2013. Youth Enterprise Development Fund (YEDF) in 2009, disbursed funds to 8586 youth groups totaling Ksh $376,923,810$ and only 83,732,085 (22.2\%) was repaid while the outstanding balances of 293,191,724 (77.8\%) was not paid (YEDF, 2009). A report from Pamoja (2010) indicated that in Kerugoya District loan default advanced to groups increased from 7.17 percent to 28.22 percent. This eventually affects the sustainability capacity of MFIs. 
Microfinance Institutions include microfinance banks, wholesale MFI's, development institutions and insurance companies (AMFIK, 2014). Microfinance has been viewed by developing countries as a strategy for poverty alleviation and human enhancement (Halvoet, 2006). Halvoet (2006) argues that in order to reach the unbankable poor and reduce costs on transaction, use of groups to intermediate is paramount. This increases chances of repayment through peer pressure and reduces time consumed on loan proceedings. According to World Bank (2006), the developing economies especially Asia, Africa and Latin America organizations deliver microfinance services that are either formal or informal. The organizations are categorized as either traditional or alternative depending on the level of community participation. The traditional microfinance is characterized by; lending of funds to the poor, external donor funding, use of Grameen bank model and less participatory and community driven.

According to Farhodova et al., (2008), these traditional MFIs do not sustain financial services due to; poor mobilization of savings, high external dependence on foreign capital that leads to less accountability and responsibility over the funds, high default rates, poor perception by community that loans provided are handouts and do not require repayment and also limited managerial skills. The alternative MFIs unlike the traditional MFIs are characterized by; saving mobilization, money lenders to members depending on their savings and follow the village bank model (Farhodova et al., 2008). The village Bank model has an objective of mobilizing members to save and have self-financing groups between 15 - 30 members who form semi-formal banks in the village (Murdoch, 2000; Holt, 1991). These MFIs are more participatory and driven by community. These alternative MFIs face several challenges namely; low savings, small loans available to members, savings not released to the member until one gets a loan, high possibility of loan default among members and lack of a legal framework (Schreiner, 2000).

In Africa, poverty is a multi-faced problem caused by low literacy levels, limited resources, low health and education services, high unemployment and lack of adequate incomes to provide basic needs to the poor (Mwaniki, 2006). Many people in Africa, about 50 per cent mostly women, live below the poverty line (less than 1 dollar per day), despite efforts made by various governments and development partners (ibid). Financial assistance is therefore considered as an anti-poverty reduction tool (Mwaniki, 2006; Chowdbury, 2009; Sjomsoeddin, 2010). In Kenya, social and economic developments are strongly affected by high poverty and unemployment rates (Lagat et al., 2012). Further, the issue is aggravated by high dependency, unemployment and under development of the youth which is challenging to the country (ibid). The government has come up with initiatives to promote entrepreneurship as an alternative strategy for creating employment through Youth Enterprise Development Fund (YEDF). At the same time women have received microcredit through the Women Enterprise Fund (WEF) by the government. These funds are channeled through Financial Intermediaries and constituencies to create small businesses.

Majority of microcredit borrowers invest their funds in small businesses. Therefore the importance of these businesses in job creation cannot be overemphasized. Small business development is effective for assisting the poor in developing economies (Zeller and Sharma, 2000). The management and running of these businesses is done by private and social entrepreneurs who play a key role in any community as "primary contributors, mobilizers of resources to develop the economy, a provider of employment for others and a stabilizing factor in society" (RoK, 1992). The government has an obligation to establish strategies to develop an entrepreneur and create conducive environment for him to use his outstanding ideas and innovations. In Kenya, since the enactment of the Microfinance Act of 2006, the microfinance industry has been vibrant in its growth, for example, Faulu and Kenya Women Finance Trust gave a total of Kshs. 14.9 billion which was granted as loans and advances and mobilized deposits that rose up to 7.2 billion (RoK, 2011).

In Kenya, MFIs are supervised by Association of Microfinance Institutions in Kenya (AMFIK) which was registered in 1999 to ensure quality service provision to the low income people and assists MFIs in building their capacity (AMFIK, 2014). These institutions are rated internationally by an agency called Microfinanza Rating. AMFIK has four strategic pillars namely; policy advocacy and lobbying, capacity building, networking and linkages, research and knowledge management. These institutions have registered a gradual growth for the last three years amounting to 298.4 billion by December 2013(AMFIK, 2014). The active clients in the sector stand at 8,809,543 and excluding banks clients' total is 1,062,621 (ibid). The dominant banks are Equity bank which consists of 72 per cent total assets, the rest are K-REP, Post Bank and Jamii Bora Bank. 2014. Some still Deposit Taking Microfinance (DTMs) such as Kenya Women Finance Bank (KWFT) SMEP, Uwezo, REMU, Rafiki, U\&I, SUMAC, Century and Faulu and others Credit-only MFIs. The microfinance institutions have received substantial support from both bilateral and multilateral donors (Chowdbury, 2009). By December 2014, a report showed that MFIs had 698 branches across the country. According to the report, Rift Valley has the highest (160), Nairobi (145 branches) followed by and Central region (102) and the least branches are found in Western (104) and North Eastern (6) branches. The sector had employed 12,377 staff and the sector without the banks has 4,856 (AMFIK, 2013). There are various policies and legislation that regulate MFIs namely: MFI Act (2006), Kenyan Banking Act(2012), Central Bank of Kenya, SACCO Act (2008), Kenya Union of Savings and 
Credit Cooperatives (KUSCCO), SACCO Societies Regulatory Authority (SASRA) and Credit Referencing Bureau (CRB) Regulation of 2008 (Warue, 2012).

Microcredit and other innovative programs reduce poverty by enhancing people's potential (Yunus, 2003) and give opportunities to the poor and unemployed, promotes their self-respect and self-esteem through self-employment. Being employed boosts the creditworthiness of those who pay back the small loans granted and therefore reduces poverty in the long run (Chowdbury, 2009). MFIs employ workers in their institutions which have great multiplier effects (Roodman and Qureshi, 2006) therefore improving peoples' standard of living (United Nations, 2006). MFIs provide financial services such as credit, savings and other social services such as group formation, training in financial literacy and development of management capabilities (ibid). Chowdbury suggests that some of these programs include management and entrepreneurial training to entrepreneurs. Microfinance is important in building a global financial system for the needy poor (Wrenn, 2005). However despite the outlined benefits of microfinance institutions default rate is a major threat to their suitability, profitability and operations.

According to Centre for the Study of Financial Innovation (CSFI) (2011), the microfinance industry has experienced a number of challenges namely; low funding, loan default rates increasing and therefore needs sustainability in poverty eradication. According to Association of Chartered Certified Accounts (ACCA) (2011), management of information asymmetry to detect early signs of those who are likely to default is paramount in avoiding serious cases of delinquencies. This calls for proper investment in resources such as; management skills, human and capital. This in return facilitates the growth of microfinance industry. A report by Financial Sector Deeping(FSD) Kenya (2009) indicated that despite the growth of Microfinance Industry, still 33\% of Kenya's population cannot access finance, hence the need to campaign to this population through education to the unbankable population.

Microcredit is disbursed through groups or individuals. By December 2013, the group lending model had a better portfolio than the individual lending model as shown in Table 1.1. Portfolio at risk (PAR) shows all arrears of outstanding loans. Portfolio at risk 30 (PAR 30) are outstanding balance on loans with arrears greater than 30 days/gross outstanding portfolio. It is an indicator to the financial institution on the current losses likely to incur and also in the future if no payments are made at all (Warue, 2012). This implies that loan default among the individuals at $13.7 \%$ is quite high compared to groups at $5.9 \%$, any amount over 5 percent calls for concern (United Nations, 2011).

Table 1.1: Portfolio at Risk 30 per Category

\begin{tabular}{|l|l|l|}
\hline PAR30 per credit methodology & Sector without banks & Whole sector \\
\hline Individual lending & $8.1 \%$ & $13.7 \%$ \\
\hline Group lending & $5.9 \%$ & $4.2 \%$ \\
\hline Individual and group lending & $14.6 \%$ & N/A \\
\hline
\end{tabular}

\section{Source: AMFIK, (2013)}

Table 1.2 presents the geographical coverage of MFIs in Kenya by regions, amount of loans borrowed, the numbers of active borrowers in each region and the average outstanding loans. The regions with the highest outstanding loan amounts were; North Eastern, Nairobi, Rift Valley, Central, and Eastern regions in that order. Nairobi also had the highest loan portfolio amounting to $25.8 \%$ of the whole sector's GLP, followed closely by Rift Valley (24.6\%) and the least was North Eastern with 0.3\% despite its high outstanding loan balance.

Table 1.2: MFI and Entrepreneurs Geographical Coverage by Regions

\begin{tabular}{|l|l|l|l|l|}
\hline Regions & $\begin{array}{l}\text { Gross Loan } \\
\text { Portfolio(GLP) } \\
\text { (Ksh billion) }\end{array}$ & $\begin{array}{l}\text { \% of the Whole } \\
\text { Sector's GLP }\end{array}$ & $\begin{array}{l}\text { Number of active } \\
\text { borrowers }\end{array}$ & $\begin{array}{l}\text { Average Outstanding } \\
\text { LoanAmount(Ksh } \\
\text { million) }\end{array}$ \\
\hline Nairobi & 13.6 & 25.8 & 150,246 & 90,793 \\
\hline Rift Valley & 13.04 & 24.6 & 183,966 & 70,874 \\
\hline Central & 7.77 & 14.7 & 122,479 & 63,473 \\
\hline Eastern & 5.74 & 10.8 & 97,607 & 58,799 \\
\hline Nyanza & 4.26 & 10.9 & 94,502 & 46,429 \\
\hline Coast & 5.00 & 9.4 & 91,152 & 54,803 \\
\hline Western & 2.36 & 4.5 & 50,544 & 46,768 \\
\hline North Eastern & 0.14 & 0.3 & 1,417 & 98,664 \\
\hline
\end{tabular}

Source: AMFIK, (2014)

Table 1.3 presents the recent data on PAR of various MFIs in Kenya per AMFIK (2014). Some of these MFIs indicated very high PAR such as; Jamii Bora, Milango Financial Service Ltd, AAR Services, SISDO, Jitegemee Credit, Mosoni Kenya, Letshego and Uwezo have had their PAR 30 at high levels consecutively for three years. It is evident from the averages PAR that since 2011 the default rate has gradually increased from 8.8 present (2011), 9.4 percent (2012) and 9.9 percent (2013). This trend is of great concern 
since PAR 30 has continued to deteriorate compared to previous years as a result of portfolio management and therefore the need to examine this phenomenon of high default rates in these institutions. In the same year 2013 according AMFIK, (2014), the write off ratios in Credit - only MFIs rose from 0.9\% (2011), 0.9\% (2012) to $1.5 \%$ (2013). This is an indicator that MFIs losses have continued to increase due to the write offs and this threatens their sustainability.

Table 1.3: Portfolio at Risk (2014)

\begin{tabular}{|c|c|c|c|c|}
\hline MFI & $\begin{array}{l}2011 \\
(\%)\end{array}$ & $\begin{array}{l}2012 \\
(\%)\end{array}$ & $\begin{array}{l}2013 \\
(\%)\end{array}$ & $\begin{array}{l}\text { Loan outstanding } \\
\text { portfolio USD }\end{array}$ \\
\hline RAFIKI DTM & - & 30.8 & 10.0 & $22,036,556$ \\
\hline MILANGO FINANCIAL SERVICE LTD & 7.7 & 17.2 & 29.7 & 969,854 \\
\hline SMEP & 8.9 & 17.2 & 14.8 & $22,826,154$ \\
\hline K-REP BANK & 16.6 & 15.8 & na & $107,555,913$ \\
\hline \multirow{2}{*}{$\begin{array}{c}\text { JAMII BORA BANK- Whole } \\
\text {-MFI }\end{array}$} & 44.8 & 15.2 & 15.8 & $45,358,853$ \\
\hline & 31.0 & 14.7 & 46.3 & $5,042,063$ \\
\hline CENTURY DTM LTD. & - & 14.5 & 6.6 & $1,025.181$ \\
\hline REMU DTM LTD. & 6.8 & 14.2 & 9.3 & $1,916,464$ \\
\hline ECLOF - KENYA & 10.9 & 10.9 & 5.8 & $6,958,860$ \\
\hline SPRING BOARD CAPITAL LTD & 11.8 & 10.3 & na & \\
\hline AAR SERVICES & 5.1 & 8.6 & 19.4 & $6,074,124$ \\
\hline PAWDED & 7.8 & 7.8 & 7.5 & $8,423,205$ \\
\hline SUMAC DTM LTD. & 7.1 & 7.3 & 6.5 & $1,056,587$ \\
\hline SISDO & 9.6 & 7.1 & 12.7 & $3,217,094$ \\
\hline \multirow{2}{*}{$\begin{aligned} \text { EQUITY BANK - } & \text { WHOLE } \\
- & \text { MFI }\end{aligned}$} & 3.5 & 6.4 & na & \\
\hline & 7.4 & 10.6 & 7.5 & $153,028,977$ \\
\hline YEHU & 3.4 & 6.2 & 3.6 & $4,151,212$ \\
\hline KADET LTD & 11.2 & 5.8 & na & $102,727,685$ \\
\hline KWFT & 6.1 & 5.7 & 6.6 & \\
\hline FAULU KENYA DTM & 5.2 & 5.2 & 5.3 & $4,934,759$ \\
\hline MICRO AFRICA LTD & 3.6 & 4.9 & na & $5,865,217$ \\
\hline JITEGEMEE CREDIT SCHEME & 2.6 & 3.5 & 6.0 & $2,779,347$ \\
\hline JUHUDI KILIMO LTD & 4.1 & 3.2 & 3.9 & 452,425 \\
\hline KEEF KENYA & - & 1.9 & 1.8 & $6,097,262$ \\
\hline SAMCHI CREDIT LIMITED & - & 1.8 & 15.7 & 285,980 \\
\hline OPPORTUNITY KENYA LTD & 0.8 & 1.4 & 3.4 & \\
\hline RUPIA MICRO-CREDIT LTD. & 2.1 & 1.3 & 1.8 & $2,781,435$ \\
\hline TAIFA OPTION MFI LTD & - & 1.2 & na & \\
\hline MOSONI KENYA & 4 & 1.1 & 3.2 & $2,781,435$ \\
\hline GREEN LAND FEDHA & - & 0.6 & 0.1 & $19,111,251$ \\
\hline BIMAS & 6.1 & 7.5 & 9.1 & $5,0005,225$ \\
\hline LETSHEGO & 3.6 & 4.9 & 5.8 & 9771,101 \\
\hline VISION FUND & 11.2 & 5.8 & 5.1 & $5,909,817$ \\
\hline U\&I MFI Bank & 22.4 & 7.1 & 10.2 & 446,963 \\
\hline UWEZO & 10.2 & 12.0 & 29.1 & 924,100 \\
\hline AVERAGE PAR & 8.4 & 9.6 & 9.9 & \\
\hline
\end{tabular}

\section{Source: AMFIK, 2014}

Public entrepreneurial funds (PEFs) disbursed by Kenyan government have faced serious challenges in loan recoveries hence recording high default rates. The Youth Enterprise Development Fund has various products that are disbursed to group and individuals and Table 1.4 presents the loan recoveries since 2012 in percentages for six loan products and also their averages per year. It is evident that the recovery rates have continued to deteriorate over the years. In 2012/2013 year the recovery rate for each product ranged from $75 \%$ (C-YES) to $90 \%$ (AGUA). This implies the default rate ranged from $10 \%$ to $25 \%$. But in 2013/2014, the recovery rates went down from $53 \%$ (C- YES) to $90 \%$ ( LPO) hence recording default rates from $10 \%$ to $47 \%$. In the period 2014/2015, the recovery rates went further down from $27 \%$ (AGUA) to $76 \%$ (LPO). This is well presented in Figure 1.1. This therefore implies that default rates went higher from $73 \%$ and $24 \%$ respectively. The situation further deteriorated in the period 2015/2016 in that AGUA recorded a recovery rate of $22 \%$ and hence recording a default rate of $78 \%$ which is quite high threatening the sustainability of the fund. AGRIVIJANA recorded a recovery rate of $34 \%$ implying that $66 \%$ was not paid back.

Table 1.4: Loan Recoveries 2012/2013 to 2015/2016 in Percentages

\begin{tabular}{|c|c|c|c|c|c|c|c|}
\hline Financial Year & $\begin{array}{l}\text { Average } \\
\%\end{array}$ & $\begin{array}{l}\text { C-YES } \\
\%\end{array}$ & $\begin{array}{l}\text { E-YES } \\
\%\end{array}$ & $\begin{array}{l}\text { VUKA } \\
\%\end{array}$ & $\begin{array}{l}\text { AGRIVIJANA } \\
\%\end{array}$ & $\begin{array}{l}\text { AGUA } \\
\%\end{array}$ & $\begin{array}{l}\text { LPO } \\
\%\end{array}$ \\
\hline $2015 / 2016$ & 62 & 78 & 92 & 80 & 34 & 22 & 63 \\
\hline $2014 / 2015$ & 66 & 73 & 88 & 83 & 44 & 27 & 76 \\
\hline $2012 / 2013$ & 85 & 75 & 86 & 94 & 80 & 90 & - \\
\hline
\end{tabular}

Source; YEDF, 2017 


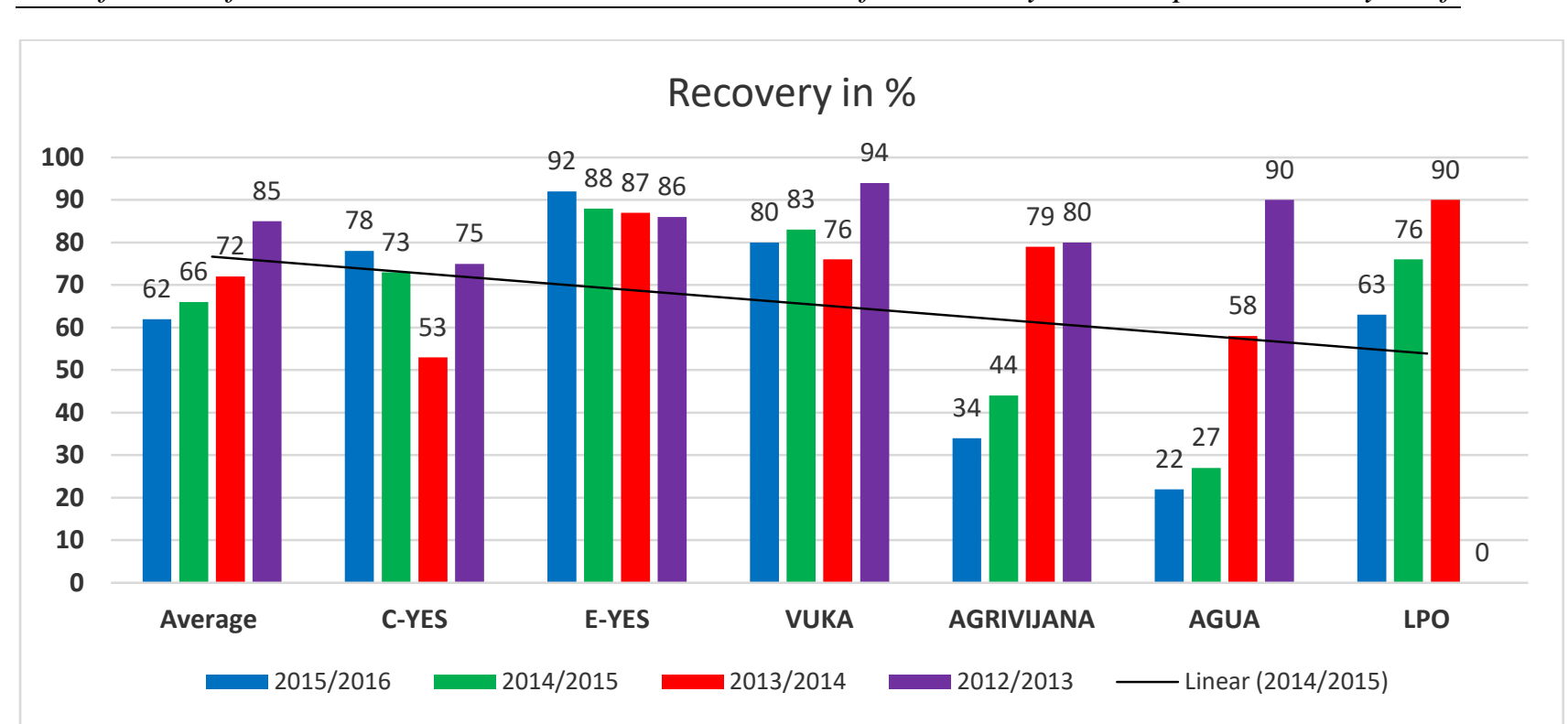

Figure 1.1 Fund's loan recovery trend from 2012/2013 - 2015/2016

The Table 1.5 presents the average rates and default rates of YEDF for the last 5 years of from the period 2012/2013 to 2015/2016. The default rates have continued to increase over the years as presented in Figure 1.2

Table 1.5: Average Default Rate for YEDF (2017)

\begin{tabular}{|l|l|l|}
\hline Financial Year & Average Recoveries (\%) & Default Rate (\%) \\
\hline $2015 / 2016$ & 62 & 38 \\
\hline $2014 / 2015$ & 66 & 34 \\
\hline $2013 / 2014$ & 72 & 28 \\
\hline $2012 / 2013$ & 85 & 15 \\
\hline
\end{tabular}

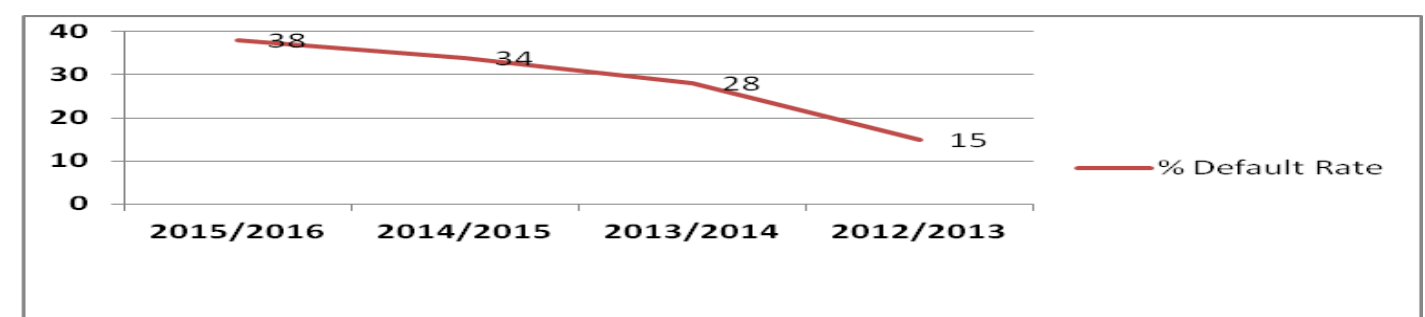

Figure 1.2: Average Default Rate Trend for YEDF (2012-2016)

The average default rate of the YEDF in 2012/2013 was $15 \%$, increased to $28 \%$ in $2013 / 2014$, a further increment was recorded in $2014 / 2015$ up to $34 \%$ and finally in $2015 / 2016$, it raised to $34 \%$ (YEDF, 2017). This can be attributed to lack of official loan recovery strategies on loan defaulters and scanty documentation on portfolio of groups and individuals (ibid). This trend should be reversed and therefore the need for the study. A study by Kiraka et al., (2013) reported that poor dissemination of information and misconception of the fund caused high default rates. Among the C-WES the default rates were between 20-30 percent compared to 10-20 percent among MFIs while in commercial banks recorded less than 5 percent (ibid).

Similarly, Uwezo Fund has faced numerous challenges just like YEDF in loan repayment. Uwezo Fund was established in February 2014, in order to address the issue of unemployment of youth and empower women and people with disabilities. The 6 billion fund has faced a number of challenges namely; refusal by groups to repay their first loans, since they believe it's a gift from the members of parliament (MPs), blame game between the MPs and Funds Oversight Board and the fact that the law does not give provisions for recovery of that cash (Gisera, 2016). According to a report from the funds oversight board 99 percent of the money had not been revolved as at June $30^{\text {th }}, 2016$. The board indicated that 5.34 billion was disbursed to 36,000 groups in Kenya and only 947 million has been recovered leaving 4.393 billion unpaid (representing 82\%). The report further says that 32 constituencies out of 290 constituencies had revolved the funds (11\%) while 258 constituencies have not revolved the funds which constitute 89 percent. This puts the sustainability of the funds into jeopardy. The default rates are very high especially in some constituencies as shown in Table 1.6. The Table presents 31 constituencies in Kenya that received over 430 million shillings. The default rate recorded on average is 68.4 percent with over 294 million unpaid. This amount is quite high being in mind that the fund was 
meant to be a revolving fund. This therefore calls for immediate intervention by the government/oversight board to put in place measures to revert the trend to avoid its collapse since its sustainability is at stake. Some constituencies had default rates recorded as $99 \%$ to $100 \%$ such as; Mandera North, East and South, Turkana West and North, Lafey, Banissa ,Moyale and Dadaab. Some of the groups that received the loans did not invest as planned, others disintegrated and stopped payments halfway (Chanji, 2016). Table 1.6 presents the loan status of WEF in 2017 as per some constituencies in Kenya.

Table 1.6 Uwezo Fund' Default Rates (2016)

\begin{tabular}{|c|c|c|c|}
\hline Constituency & Allocated Kshs. & Unpaid Kshs. & \% unpaid \\
\hline Mandera South & $31,795,213$ & $31,531,713$ & 99.9 \\
\hline Turkana West & $29,449,686$ & $29,449,186$ & 100 \\
\hline Mandere West & $24,838,046$ & $24,838,046$ & 100 \\
\hline Lafey & $24,255,564$ & $24,255,564$ & 100 \\
\hline Banissa & $24,661,127$ & $24,661,127$ & 100 \\
\hline Mandera North & $25,589,527$ & $25,421,542$ & 99.9 \\
\hline Turkana North & $24,334,336$ & $23,749,336$ & 97.6 \\
\hline Dadaab & $19,000,000$ & $18,996,940$ & 99.9 \\
\hline Mandera East & $19,800,000$ & $19,795,000$ & 99.9 \\
\hline Moyale & $18,000,000$ & $17,977,800$ & 99.9 \\
\hline Tongaren & $7,860,417$ & $3,582,516$ & 46 \\
\hline Kaloleni & $8,477,883$ & $4,222,336$ & 50 \\
\hline Teso North & $7,867,917$ & $3,615,607$ & 46 \\
\hline Manyatta & $9,101,667$ & $4,880,895$ & 54 \\
\hline Matungulu & $8,272,083$ & $4,058,011$ & 49 \\
\hline Lurambi & $9,251,667$ & $5,050,442$ & 55 \\
\hline Alomui & $8,539,167$ & $4,356,691$ & 51 \\
\hline Seme & $8,202,083$ & $4,038,668$ & 49 \\
\hline Buretti & $8,529,167$ & $4,600,205$ & 54 \\
\hline Nyakach & $8,615,000$ & $4,769,836$ & 55 \\
\hline Sirisia & $9,650,833$ & $5,972,278$ & 62 \\
\hline Sigowet/Soin & $8,063,750$ & $4,247,660$ & 53 \\
\hline Vihiga & $8,135,000$ & $4,465,267$ & 55 \\
\hline Ndhiwa & $9,781,458$ & $6,456,735$ & 66 \\
\hline Mt Elgon & $11,708,125$ & $8,471,934$ & 72 \\
\hline Kapenguria & $8,300,000$ & $5,444,176$ & 66 \\
\hline Konoin & $6,403,750$ & $3,592,997$ & 56 \\
\hline Rarienda & $6,442,500$ & $3,718,078$ & 57 \\
\hline Kangundo & $8,000,000$ & $5,294,226$ & 66 \\
\hline Kasarani & $6,537,500$ & $3,859,000$ & 59 \\
\hline Igembe North & $5,983,333$ & $3,304,462$ & 55 \\
\hline TOTALS & $430,809,715$ & $294,673,845$ & 68.4 \\
\hline
\end{tabular}

\section{Source: Uwezo Fund Oversight Board, 2016}

The Women Enterprise Fund suffered high default rates just like the Uwezo Fund and YEDF. Table 1.7 indicates the WEF loan status of some FIs as released from the Credit Department by April 2016. It is evident from the table that funds released to these FIs indicate high outstanding balances on average $49.06 \%$. This raises concern why such default rates are witnessed and therefore the need to carry out a research to examine this phenomenon.

Table 1.7: FIs WEF Loans (2016)

\begin{tabular}{|c|c|c|c|c|c|}
\hline \multicolumn{6}{|c|}{ WOMEN ENTERPRISE FUND (WEF) } \\
\hline \multicolumn{6}{|c|}{ Credit Department } \\
\hline \multicolumn{6}{|c|}{ FIs loans as at 26.04.2016 } \\
\hline \multicolumn{6}{|c|}{ Loan Amount (in ‘000,000’ Kshs) } \\
\hline FIs & Total Allocation & $\begin{array}{l}\text { Total } \\
\text { Released }\end{array}$ & $\begin{array}{l}\text { Amount } \\
\text { Repaid }\end{array}$ & $\begin{array}{l}\text { Balance } \\
\text { Outstanding }\end{array}$ & $\begin{array}{l}\text { Outstanding } \\
\text { Balances in \% }\end{array}$ \\
\hline African W.Foundation & 4 & 2 & 0.9 & 1.1 & 55 \\
\hline ARDESC SACCO & 8 & 4 & 0.95 & 3.05 & 76.25 \\
\hline Chase Bank & 50 & 50 & 30 & 20 & 60 \\
\hline Gusii P.SACCO & 1 & 1 & 0 & 1 & 100 \\
\hline Jisaidie & 13 & 7 & 3.1 & 3.9 & 55.7 \\
\hline Jihahidi & 4 & 3 & 1.8 & 1.2 & 40 \\
\hline Kia -Mokama & 15 & 13.5 & 10 & 3.5 & 35 \\
\hline Kijito & 3 & 3 & 0 & 3 & 100 \\
\hline OLmarel Lang & 5 & 5 & 0.472 & 3.528 & 9 \\
\hline Pambazuka Merinaoh & 2 & 2 & 1.303 & 0.697 & 34.9 \\
\hline Tetu women & 1 & 1 & 0.45 & 0.55 & 55 \\
\hline
\end{tabular}


Influence of Business Characteristics on Microcredit Default in Kenya: a Comparative Analysis of

\begin{tabular}{|l|l|l|l|l|l|}
\hline Uchumi Bora & 4.5 & 1.5 & 0 & 1.5 & 100 \\
\hline UWESO & 8 & 8 & 5 & 3 & 37.5 \\
\hline Webuye Devpt Coop & 1 & 0.64 & 0.048 & 0.592 & 92.5 \\
\hline Wells Community & 11 & 11 & 2 & 9 & 81.8 \\
\hline WAADI & 10 & 10 & 6.45 & 3.55 & 35.5 \\
\hline Total & $\mathbf{1 4 0 . 5}$ & $\mathbf{1 2 2 . 6 4}$ & $\mathbf{6 4 . 4 7 3}$ & $\mathbf{6 0 . 1 6 7}$ & $\mathbf{4 9 . 0 6 \%}$ \\
\hline
\end{tabular}

Source: WEF, 2016

The provision of microcredit in most developing countries depends on various assumptions; firstly borrower's willingness to repay the loan, secondly capital is the only way to finance the microenterprise, and lastly the borrowers become creditworthy by being disciplined in loan repayment (Pretes, 2002). Pretes further noted that micro credit programs experience a serious default problem of borrowed funds. Nawai (2010) suggested that microcredit is geared towards the growth of entrepreneurship among the poor people to help them out of poverty. These are people who lack collateral, stable employment and lack credit history hence not able to meet the conditions of the traditional financial institutions (ibid). According to Robinson (2002), microfinance is a developed approach that involves financial assistance and social intermediation. The financial aspect provides services such as savings, credit and insurance while in social intermediation, citizens are organized in groups that facilitate policy makers to attend to them and meet their aspirations and concerns.

Loan default appears to be a major problem everywhere. Loan default is generally said to be a serious problem in Africa and has been experienced in some cases in many countries. According to Okorie (2004), "poor loan repayment in developing countries has become a major problem in credit administration to smallholders who have limited collateral capabilities". Financial Institutions are discouraged from giving more credit to the defaulters; therefore defaulters find themselves in the same problem of low productivity (ibid). Handling loan repayments effectively 'reduces distress and shaky foundation for the establishment of MFI's (Olagunju and Adeyemo, 2007).

A report from Pamoja (2010) indicated that in Kerugoya District loan default advanced to groups increased from 7.17 percent to 28.22 percent. This adversely affects sustainability capacity of MFIs. The default rate among MFIs' sector is relatively higher compared to commercial banks with default rates ranging from $10 \%-20 \%$ while commercial banks have a less than 5\% default rate (Kiraka et al., 2013). In their study, the constituency women enterprise recorded 20-30\% default rate in 2013. Youth Enterprise Development Fund (YEDF) in 2009, disbursed funds to 8586 youth groups totaling Ksh 376,923,810 only was 83,732,085 (22.2\%) repaid while the outstanding balances of 293,191,724 (77.8\%) was not paid (YEDF,

A study by Mungai, Maingi and Murathe (2014) in Muranga county indicated that government funded micro-credit registered high default rate due to the fact that there was high snow balling among the borrowers who argued that 'if others do not pay' why should one pay, others treat the fund as a gift from the government and therefore not intended to be paid back (ibid). The study also reported that the fund was coupled with high risk and high cost of borrowing, limited capacity for the normal borrower to repay and also borrower's irregular incomes and therefore there is need to come up with policies to ensure constant incomes among the borrowers. It is evident from the averages PAR 30 observed in MFIs that since 2011 the default rate has gradually increased from 8.8 percent (2011), 9.4 percent (2012) and 9.9 percent (2013) as presented. This trend is of concern since PAR 30 has continued to deteriorate compared to previous years as a result of portfolio management and therefore the need to examine high default rates in these institutions. In the same year 2013 according AMFIK, (2014), the write off ratios in Credit -only MFIs rose from $0.9 \%$ (2011), $0.9 \%$ (2012) to $1.5 \%$ (2013). This is an indicator that MFIs losses have continued to increase due to write offs and threatening their sustainability.

The average default rate of the YEDF in 2012/2013 was 15\%, increased to $28 \%$ in 2013/2014, a further increment was recorded in 2014/2015 up to 34\% and finally in 2015/2016, it raised to $34 \%$ (YEDF, 2017). Uwezo Fund reports indicate that 5.34 billion disbursed to 36,000 groups in Kenya, 4.393 billion remain unpaid (representing 82\%). The report further says that 258 constituencies out of 290 constituencies (89 percent) had not revolved the funds. This implies that the funds have not been repaid.

Bichanga and Aseyo (2013) carried out a study on microcredit and examined three parameters; supervision, shrinking economic growth and diversion of loan default. Ngahu and Wagoki (2014) explored the influence of group lending management on loans among MFIs, Moti et al., (2012) concentrated on the effectiveness of credit management on loan performance in MFIs and Warue (2012) examined the external factors and group factors on loan default in MFIs. From these studies much has been done on economic factors and group factors and their influence on loan default. Delinquency is a case of concern to both MFIs and FIs since it increases risk of losses, sign of operational problems and helps to predict the amount of portfolio that is likely to be lost if not paid (Warue, 2012). According to Stearns (1991), delinquency of loans affect MFIs and FIs programs in both measurable and immeasurable ways; it causes postponed or loss of income, rotation of portfolio eventually slows and reduces asset productivity, increases costs of follow-ups on delinquency cases, image of the programme in diminished and increases loan loss and reserve costs. It is believed that every 
borrower is willing to repay the loan borrowed but there are factors that hinder or frustrate his intentions. This study sought to assess the influence of business characteristics on microcredit default rates both in MFIs and FIs disbursing public entrepreneurial funds in Kenya.

\subsection{The Statement of the Problem}

Both Microfinance Institutions and the Kenyan Government have initiatives to reduce poverty among the poor through provision of microcredit and disbursements of funds to youth and women respectively. The issue of loan default is a major concern in Kenya. When loans are disbursed, it is not clear how the money is utilized and the follow up by lenders is a challenge. Many credit institutions have registered heavy losses as a result of loan default. Women Enterprise Funds by June 2016 recorded on average 49.06 percent as outstanding loans while Uwezo Funds in 2016 indicated that 5.34 billion was disbursed to 36,000 groups in Kenya and only 947 million had been recovered leaving 4.393 billion unpaid (representing 82\%). However literature review and information from focus groups indicate that though credit is available to MSEs, entrepreneurs have challenges refunding the total credit borrowed and many questions therefore have arisen in this regard. Causes for delinquency and probable default are argued to include; poor appraisal and risk assessment systems, ineffective training on proper funds management, untimely disbursement of funds applied for, irregular loan supervision and follow-up during the loan period to check on delinquency among others. Loan default causes the defaulter to lose chances of accessing more credit in future while the lender increases losses and non-performing loans which consequently reduce funds to advance to more businesses and risks institution's sustainability. The success of credit institutions largely depends on management of credit advanced and therefore the need to minimize loan default rates. This study therefore sought to examine causes of high loan default rates in both MFIs and FIs as a result of business characteristics with an aim of reducing portfolio at risk in these institutions and making recommendations to MFIs, FIs and policy makers.

\subsection{Objective of the Study}

The study sought to examine the influence of business characteristics on loan default in MFIs and FIs in Kenya. 1.3 Research Hypothesis

The research sought to address the following hypothesis;

$\mathrm{H}_{01}$ : Business characteristics are not significant in influencing loan default within MFIs and in Kenya

\subsection{Significance of the Study}

The study aimed at examining the influence of business characteristics on loan default in MFIs and FIs in Kenya which is a comparative study. The results will be beneficial to small businesses, financial institutions, policy makers and scholars.

\section{Literature Review}

Globally microfinance fulfills one objective of facilitating accessibility of financial services to the “poor and marginalized sections of the community" ((Reserve Bank of Zimbabwe, 2012).). MFIs provide small loans and at times also expand their products to include micro-deposit and micro-insurance products (Orrick et al., 2001). Microfinance has been a channel through which the poor alleviate poverty by adopting some strategies as outlined by Dadzie et al., (2012) such as; engaging the informal economy whereby 50 percent of people derive their source of livelihood, mobilization of micro-saving therefore expanding the MFIs deposits and increase the capital base of these institutions, investing in women hence increases economic equality and improves the life of women and their households, facilitating national and international money remittances, facilitating development of local private sectors and helps to invest in, promoting slum conditions for slum dwellers such as homes and income generation activities and finally promoting rural areas and food production. Microfinance services have three sources namely; formal MFIs, semiformal institutions such as NGO's and informal sources (Atieno, 2001; Dadzie et al., 2012). MFIs collaborate with some commercial banks to provide financial services (Dadzie et al., 2012). Microfinance has four features namely; group lending method, targets women, offers graduated loans and their interest rates are higher than traditional banks (Ruben, 2007). Microfinance programs deal with small groups who receive loans. Each member is liable and takes responsibility of a member who defaults on a particular loan. Joint liability is normally taken as the collateral (Ruben, 2007). Group lending enhances enforcement and reliable repayment (Ruben, 2007). The group lending model uses social collateral rather than material collateral (Schurmann and Johnson, 2009). The model at times discourages people who must take responsibility when their members default. Microfinance targets mostly women because women are better in loan repayment than men (Proscovia, 2013; Magali, 2013 and Yegon et al., 2013). Reuben (2007) noted that women are better managers in loans' utilization in businesses and therefore improve their livelihoods. The number of women entrepreneurs has continued to increase worldwide and their representation is one third of all entrepreneurs (GEM, 2004). MFIs target women to give them a voice to make decisions at home, in the local community and society at large (Farhodova, 2008). Chen and Mahmud (2003) 
argue that women need to exercise agency by formal schooling, active involvement in labour force and gaining capabilities for change. Mayoux (1999) argues that targeting women in microfinance to empower them in three ways through financial assistance, poverty alleviation and feminism while Chen and Mahmud (1995) introduced four elements of empowerment namely; material, cognitive, perceptual and relational.

Kabeer (1999) suggests that empowerment of women depends on their ability and determination to make choices and improper decision is disempowering. MFIs usually have a policy of graduated loans whereby the beneficiary of the loan starts small loans after which she/he gets another high amount when the repayment is done (Ruben, 2007). Interest rates charged by MFIs are relatively high, Grameen bank charges 20 percent due to overhead and transaction costs (Ruben, 2007). According to Orrick et al., (2012), interest rates charged by MFIs are higher than other banks in order to cover costs. It is expensive to provide small loans to many customers than larger amounts to few clients. Ruben compared other regions in the world and noted that Asia charged 18.9\%, Europe 20\%, Latin America 23.3\% and Africa 38.2\% (ibid). Interest rates charged depend on amount of loan, possibility of default and labor involved in loan follow up. A study in Bolivia revealed that high interest rates deterred economic development as sighted by Ruben (2007) and women who had taken loans sold some of their household items to make payments; others had to reduce food quantity and quality at home, others borrowed money from friends and others had to do manual jobs to pay the loans. Wanambisi and Bwisa (2013) noted that many MSEs had 'closed their stores due to inability to repay loans and also interests'.

Goetz and San Gupta (1996) argued that though microcredit empowers the poor, it still poses challenges in that; it may lead to worsened gender relationships and women disempowerment; it causes a burden of debt collection to the women through timely payments that may cause family problems, it also causes loan diversion, increases women's labour and insists of getting social collateral through groups to reduce loan defaults.

\section{Public Entrepreneurial Funds}

MSEs are faced with changes of growth and long term survival. The government of Kenya has introduced various support initiatives on MSEs. These initiatives include provision of entrepreneurial funds such as; Women Enterprise Funds (WEF), Youth Enterprise Development Fund (YEF), Kenya Industrial Estates (KIE) Funds and Uwezo Fund. These funds are aimed to; improve competition of MSES, to promote socialeconomic development, reduce poverty among entrepreneurs and increase financial accessibility, productivity and innovation (Gitau and Wanyoike (2014). The government has also tried to come up with support systems on MSEs which include; incubation and development services and therefore established KIE as an institution to offer "financial, incubation and business development services to MSEs in the whole country" (ibid). KIE plays a key role in ensuring MSEs survive. According to Smilor (1987) incubators are beneficial in four ways; ensuring that the entrepreneurial learning curve is shortened, offering fast solutions to businesses, ensuring businesses are accessible to other entrepreneurial networks and to facilitate business development. Incubators are used for accelerating entrepreneurial process systematically and help overcome uncertainties at the early stage of a business development.

The Youth Enterprise Development Fund (YEDF) was introduced by government in June 2006 as a strategy to address the alarming youth unemployment in the country (YEDF, 2014). The fund was supposed to address the problems faced by youth owned enterprises and its objectives include; provision of loans, facilitate and attract investors to establish industrial parks, incubators and markets' facilitation, to facilitate business linkages for youth enterprises, facilitate domestic and international marketing of youth products /services, creation of job opportunities in the international labour market and provision of enterprise development services (ibid). These funds are disbursed to youth groups and individuals and are available in all constituency offices in Kenya. The loans occur in various forms namely; E-Yes (for individual), Vuka (for business expansion), Agrivijana (for green house), Anguka Chicks (for poultry incubators), Take 254 (for films) and Credit Guarantee Scheme. By the end of December 2013, a total of 260,533 enterprises had benefitted from the fund with a total disbursement of Ksh 9,306,385,519/90 through 76 financial intermediaries in Kenya (ibid).

Women Enterprise Fund is a unique program initiated by the government to empower women economically, socially and politically (SLE, 2010). This is because majority of Kenyan women are in the informal sector and generate little income and therefore the need to boost their incomes, reduce poverty, increase efficiency and hence increase their national output (ibid). It was initiated to meet the MDGs on gender equality and women empowerment through provision of affordable credit to women for starts up and business expansion. This was to facilitate wealth creation and employment (Machira et al., 2014). The main objectives of the fund is to; provide affordable credit to women for enterprise development, build women's capacity, promote market from the products locally and internationally, promote networks for SMEs and invest in infrastructure in support of women enterprises (KIPPRA,2010). The funds channeled through constituencies as C-WES i.e. Tuinuke Loan (for self-help groups) and through intermediaries partners as Jimarishe Loan (for women self-help groups and individuals at $8 \%$ interest rate (WEF, 2014). The WEF provides the following graduated loans for a 
grace period of $1-2$ months in Table 2.2: The C-WES loan is given at zero interest rate. The graduated loans help to build the credit history of the borrower.

Table 2.1: Loan Amounts for C-WES Loan

\begin{tabular}{|l|l|l|l|}
\hline New Cycle Amounts & Grace Period & Administration Fee & Interest Rate \\
\hline 100,000 & 2 months & $5 \%$ & $0 \%$ \\
\hline 200,000 & 1 month & $5 \%$ & $0 \%$ \\
\hline 350,000 & 1 month & $5 \%$ & $0 \%$ \\
\hline 500,000 & 1 month & $5 \%$ & $0 \%$ \\
\hline
\end{tabular}

Source: Women Enterprise Fund (2014)

\section{Theories}

The study was based on Pecking Order theory and Solidarity Group Theory. Pecking order emphasizes the need for business funding preference by considering internal funds first after which a business can go for external funding while Solidarity Group Theory examines group lending as an appropriate method of reaching many poor people that use social collateral.

\section{Business Characteristics}

Several studies have been carried out on the relationship between business characteristics and loan default. Munene and Guyo (2013) conducted one on the influence of business characteristics as a variable on the loan default in Imenti North District, Kenya. They used a sample of 400 borrowers and 37 loan officers and measured parameters such as; age, type, location, profit, business management and the number of employees to measure business characteristics. The results showed that loan default was high in the manufacturing sector at $67.9 \%$, followed by the service industry and thirdly agriculture. It was noted that businesses that had operated between 5-11 years had the highest loan default and those located within the municipality recorded high default cases. Out of the parameters measured the following factors considered significant; type of business, age of the business, number of employees and business profits.

The types of business that entrepreneurs engage determine the possibility of generating high incomes to pay loans. Most businesses involved in agriculture, animal husbandry and fisheries have a possibility of loan default than others as a result of weather changes that affect production (Mokhtar et al., 2012). Magali (2013) noted that the main occupation of microcredit borrowers in Tanzania was agriculture (83.3) percent, the rest 12.5 percent were in business, 3.2 percent in permanent employment and 0.9 percent in technical work. He noted that default rate of $13 \%$ was recorded for those in agricultural activities while the rest registered 9 percent. Agricultural activities that depend on rain fed farming demonstrated an increase riskiness since the farmer has no control over production and marketing elements (Wrenn, 2005). Sileshi et al., (2013) in their study in Ethiopia established that adequate rainfall in agro-ecological area reduces the probability to default by 22.73 percent and increases the rate of loan repayment by 12.69 percent. According to Proscovia (undated), no significant difference was found between trade and agriculture in his study, however he found formal agricultural performance better than trade especially the animal husbandry sector which contradicts a study by Ledgerwood (1998), who noted that agricultural business credit demonstrated higher risk due to fluctuations in production causing differential loan performance. Findings from Majeeb Pasha and Negese (2014) revealed that $75 \%$ of clients involved in non-agricultural businesses paid their loan better than those in agricultural businesses.

Addisu (2006) in Ethiopia noted that the amount of monthly sales are directly related to loan nonpayment, businesses mainly finance their loan repayments by use of cash flow that is created by the firm (Wang and Zhou, 2011). According to Chen (2004) in China, the following factors are important in determining capital structure of the firm: profitability, size, growth opportunity, asset structure, cost of financial distress and effects of tax shields. Mashatola and Darroch (2003) in their study on loan status of sugarcane farmers in Kwazulu-Natal, South Africa revealed that business size and liquidity are major factors in determining loan repayment. Acquah and Addo (2011) used multi regression model to explain loan repayment among on fishermen in Central Region, Ghana and revealed in his findings that loan default depends on; fishermen's' income, loan size and amount of investment. The model explained $77 \%$ of the variation in the loan repaid. This implies that there are more factors excluded in the study that explain the remaining $23 \%$ that the model did not address which needs to be tested. The study revealed that $70.1 \%$ of the fishermen had delayed repayment due to 'low catch and high debts from fish mongers' (ibid). Weele and Markowich (2001) in their study on how to manage high and hyperinflation, a case of Bulgaria and Russia, pointed out that high or hyperinflation economic conditions contribute significantly in reducing businesses' ability to repay loans. Tundui and Tundui (2013) in Tanzania revealed that multiple enterprises are negatively and significantly related to loan repayment. This implies that, the more businesses the borrower has the less the problems of loan repayment. This is because the borrower is able to use profits generated from those other businesses to pay the microcredit granted to the firm. 
Magali (2013) in Tanzania noted that more years in business experience reduces loan default as a result of skills accumulated by the individual over time. Skills help one to manipulate business environments and hence able to prevent loan default. Addo and Twum (2013) argued that substantial business experience improves productivity and capital base which in return reduces the possibility of loan default. According to Tundui and Tundui (2013), the numbers of years one operates a business is not significant in determining the capacity of the borrower to repay loans, however the number of years one has been a member of microcredit programme increases business experience which translates into good business management which eventually improves efficiency and better loan repayment.

Business location is another factor to consider in loan default. According to Proscovia (undated), in Uganda, business location was found to relate to loan default considering the business income and assets. They argued that a favorable business location improves business sales and subsequently its profit and income.

Studies done by Tundui and Tundui (2008), Ledgerwood (1998), Adoyo (2013), Munene and Guyo (2013), Olagunju and Adeyemo, (2007), Magali (2013) and Addo and Twum (2013) addressed a number of MFI factors that influence loan repayment, however some parameters have not been raised. Parameters location and age of business were done in FIs in Kenya by Munene and Guyo but not in MFIs. This current study addressed the same factors in MFIs and in addition, other parameters that were not included in their model which include; borrowers experience in business, size, business' portfolio and market competition. The loan officers were used as a population in the current study both in MFIs and FIs while Munene and Guyo used borrowers as their population which raises different perceptions on loan default. Studies done outside Kenya did not examine factors in FIs which the study addressed. This will help to test the results and check whether they can be duplicated in other places in Kenya.

\section{Conceptual Framework}

The conceptualization of this research attempted to link loan default, the dependent variable and loan characteristics, the independent variable .This relationship is illustrated in Figure 2.1.

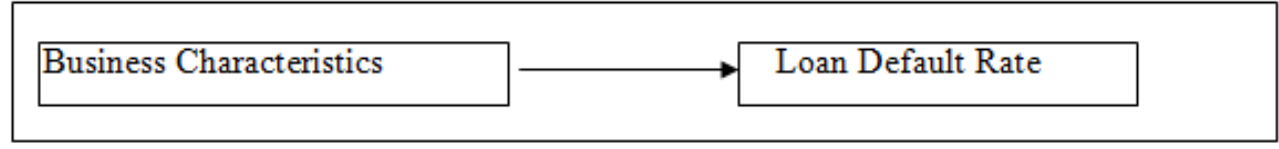

Figure 2.1: Conceptual Framework

Loan characteristics are factors relating to loan accessibility and its repayment which include; loan size, repayment mode, repayment period, type of loan and loan interest. Loan characteristics were measured in terms of amount of loan, repayment mode, repayment period, type of loan and loan interest.

\section{Research Methodology}

Research methodology involves procedures used for examining the research objectives (Oso \& Osen, 2009). Leedy and Ormrod (2001) define research methodology as "the general approach a researcher takes in carrying out a research project". There are mainly two types of philosophies used in research namely positivism and phenomenological. Positivism in basically a scientific or empirical method, and objective while phenomenological is qualitative in nature, humanistic or interpretative (Sedgley, 2007). Descriptive survey was used in order to thoroughly investigate the population through the sample in relation to loan factors that contribute to loan default in MFIs and FIs in Kenya. Both quantitative and qualitative methods were used to address the stated objectives. The study targeted a finite population of all 48 MFIs registered and operating in Kenya as per AMFIK (2013) and 76 FIs registered as per WEF (2014). These institutions have various branches across the country. The sample consisted of 48 MFIs selected from 4 counties and 48 FIs.

In order to investigate the research objectives in chapter one, both primary and secondary data were used. A questionnaire with closed and open questions was used to balance the quality and quantity of data collected. The data collection process involved training of research assistants, after which they were sent to the selected counties in the sample to collect data. An authority letter from the university granting permission for data collection was used and introductory letter to the respondent by the researcher was used. A pick and drop method was used and each respondent was given 2-3 days to fill the questionnaire which was then collected. A pilot study to measure validity of the instrument which was not included in the analysis was done. Prior to launching a full-scale study, the questionnaire was pre- tested in MFIs and FIs in Mukurweini Town to ensure its workability in terms of: structure, content, flow and the time it takes to complete it. The opinion of research experts was also sought to proof read the instrument to check on the quality of the questionnaire and enhance validity. Reliability was tested by use of Cronbach Coefficient Alpha to confirm internal consistency of each variable measured. 
Descriptive statistics were used and also inferential statistics used to draw conclusions about existing relationship and differences in the research results already found. Factor analysis was used to estimate the most significant variables which were tested in the model. A multiple regression model and Pearson correlation was used to establish relationship among variables. Data was presented by use of tables, bar graphs and pie charts and the sample statistics were used to make conclusions about the population. In order to determine the extent of loan default among MFIs and FIs, SPSS Version 21 was used to analyze data. Descriptive statistics were used to find the means and standard deviation of each variable. Standard deviation gives the distribution of scores around the mean of the distribution.

Business characteristics parameters used were; type of business, operating multiple businesses, age of business, size of business, product diversification, competition. Each parameters was measured by 5 -point Likert scale (I -strongly disagree.2-disagree, 3- Neutral, 4-ageee and 5- strongly agree). Loan default was measured by use of portfolio at risk. Factor analysis was performed on all parameters that measured each independent variable to examine the extent of correlations, and summarize and reduce the less important variables as per their factor loadings.

Exploratory Factor Analysis was performed to measure internal consistency /reliability of the measuring instrument (questionnaire) by calculating Cronbach alpha coefficients. The Kaiser-Meyer-Olkin (KMO) Measure of Sampling Adequacy and Bartlett's Test of Sphericity were used to test the suitability of the data and number of factors to be extracted. The correlation statistical technique was used to explain the degree of association between the variables. Multiple regressions were performed on all the parameters of each parameter against the dependent variable in order to test the following null hypothesis; $\mathrm{H}_{01}$ : Business characteristics are not significant in influencing loan default within MFIs and FIs. Regression analysis is formed from correlation coefficients of independent variables that is expressed in form of $Y=\beta_{0}+\beta_{1} X_{1}+\beta_{2} X_{2}+\beta_{3} X_{3}$ $+\beta_{4} X_{4}+e$ which is an equation for the best line of fit.

\section{Data Analysis, Presentation And Discussion}

The researcher distributed 48 questionnaires to MFIs and 48 to FIs. Out of the total distributed in MFIs 36 were returned fully filled and 38 for FIs. The response rate was therefore 75 percent and 79 percent respectively. This response rate was considered adequate for the study and therefore the responses could be used for the comparative study. According to Mugenda and Mugenda (1999) response rate above $70 \%$ is considered good in a survey research. The study revealed gender parity in MFIs and FIs. In MFIs $68.5 \%$ were males while in FIs the males constituted $63 \%$. This implies that majority of the loan officers were men. Loans approved by male officers increase loan default by $0.35 \%$ within one year compared to females (Agarwal and Itzahak, 2012).

Majority of clients were individuals accounting for 54.1\% in MFIs and $41.7 \%$ FIs .The type of clients served was important in the study since people receiving loans as groups have peer pressure to pay unlike the individuals. This explains that default rate is likely to be high since individuals of microloans do not use collateral unlike self-help groups that use social collateral. This implies that members are used as guarantors against any loan given to a member. These credit institutions should lay more emphasis on group funding other than individual funding to reduce defaults. This concurs with Tundui and Tundui (2008) who observed that group lending model has various advantages in that it assists MFIs to classify and identify risks, tests cases of diversion and facilitates loan enforcement in members' repayment. In MFIs, the respondents with less than 2 years' experience constituted $33.7 \%$ and 2-3 years $39.3 \%$ and $23 \%$ above 3 years as presented in Figure 4.1 . Therefore those with less than 3 years' experience constituted $73 \%$ while in FIs majority of the respondents had less than 2 years' experience (58.3\%), 2-3 years was $25 \%$ and over 3 years was $16.7 \%$. Therefore $83.3 \%$ had worked as loan officers for less than three years in FIs. This implies that the experience of handling clients is limited and therefore scrutinizing clients and their credit history may be a challenge. This study concurs with Gatimu et al., (2014) that majority of loan officers are less experienced in handling loans and possibility of tracking the clients' history may be a challenge and therefore the need for institutions to place officers who are well exposed to loan procedures to manage the credit section which eventually may reduce loan default.

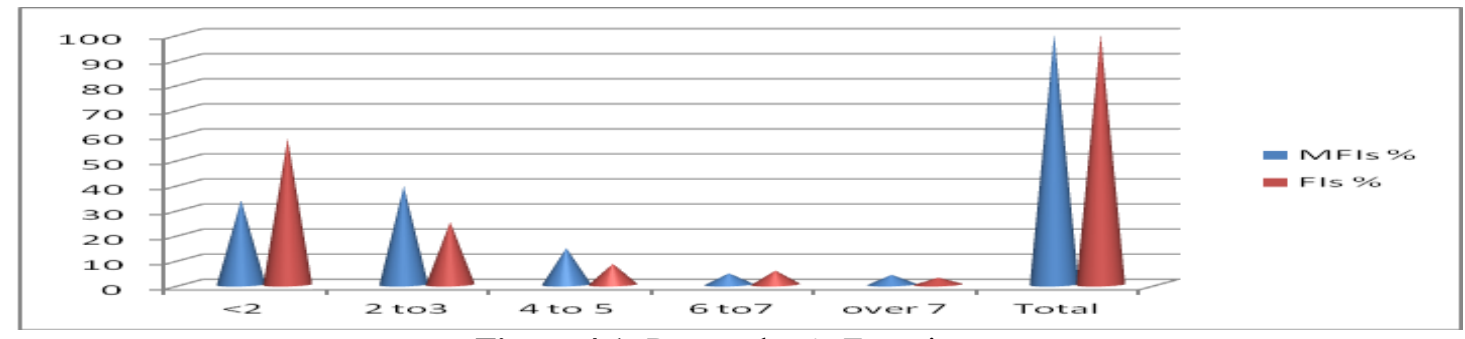

Figure 4.1: Respondent's Experience 
Age of respondents in MFIs indicated that less than 25 years was 37.1\%, 26-35 years was 55.1\% and over 35 presented $7.9 \%$ as presented in Figure 4.2. These first two groups constituted $92.1 \%$ while the same groups in FIs had the following percentages; those with less than 25 years were $19.4 \%$ and $26-35$ years were $72.2 \%$, both groups constituted $91.6 \%$ and those over $35 \%$ presented $8.4 \%$. The implies that most loan officers are less than 35 years which is a clear indication that most loan officers offering microcredit in MFI and FIs are the youth Onyeagocha, et al., (2012) concluded that the higher the loan officer's experience, the higher the possibility of recovering greater amount of loan. This argument disagrees with Agarwal and Itzhak (2012) who suggested that older loan officers approve more loans than medium- aged officers by $3.1 \%$ which eventually raises the default rate by 27.9 percent.

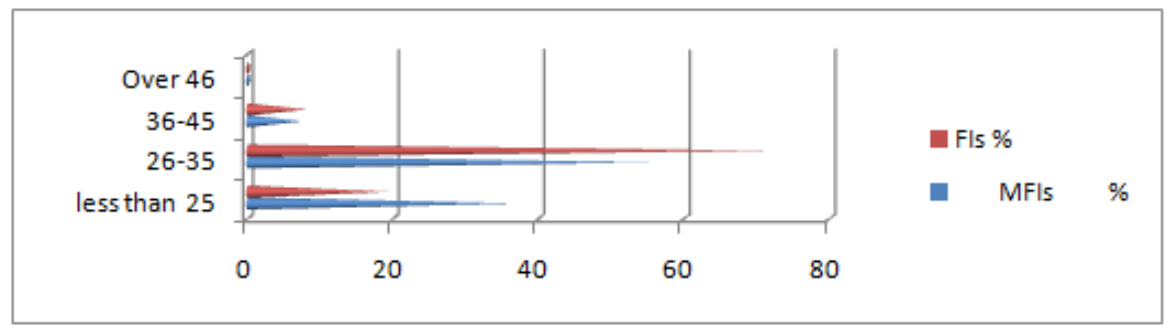

Figure 4.2: Respondent's Age

It was observed from that majority of the borrowers as shown in Table 4.3 default during the "first disbursement" (42.7\%) and "beyond the second disbursement" (47.2\%) for MFIs and $36.1 \%$ and $52.8 \%$ respectively the most defaulted disbursements. It is important that MFIs do not assume that the client is able to pay any loan; the due screening process should always be followed at all times. This is consistent with Pollio and Abuodie (2010) in his study in Ghana that loan repayment among repeat borrowers deteriorate with time compared with new borrowers.

Table 4.3: Most Defaulted Disbursements

\begin{tabular}{|l|l|l|}
\hline Number of Disbursement & MFI \% & FIs \% \\
\hline First Disbursement & 42.7 & 36.1 \\
\hline Second Disbursement & 10.1 & 11.1 \\
\hline Beyond Second Disbursement & 47.2 & 52.8 \\
\hline Total & $\mathbf{1 0 0 . 0}$ & $\mathbf{1 0 0 . 0}$ \\
\hline
\end{tabular}

The average default rate for MFIs in the year 2014 was $6.91 \%$ which is relatively high while that one for FIs was at 6.25. This was slightly lower than for MFIs. Figure 4.3 shows the average loan default among the MFIs for the last three years (2012-2014). The highest number of institutions had a default rate between $4-9 \%$ consisted of 50.6 \% and 10-14 were 12.4\% while those in FIs had 52.8\% and $11.2 \%$ respectively. According to United Nations (2011), the accepted world default rates is less than 5\%, this implies that the credit institutions need to take critical measures to reduce this trend.

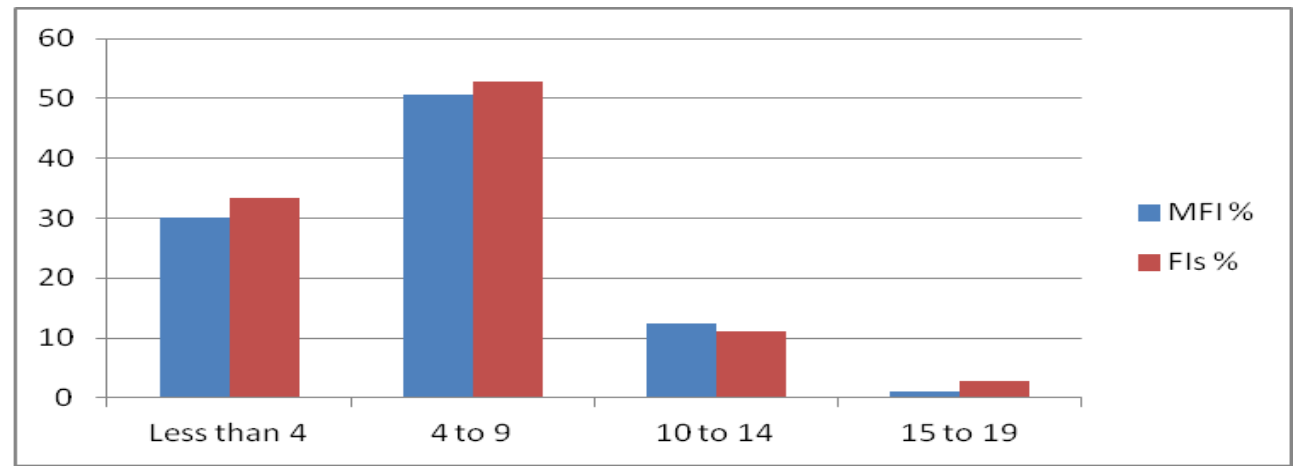

Figure 4.3: Distribution of MFIs and FIs Loan Default Rate

\section{Business Characteristics and Loan Default}

The second objective of the study was to explore the influence of business characteristics on loan default in MFIs and FIs and therefore test the null hypothesis that stated; $\mathrm{H}_{0} 1$ : Business' characteristics are not significant in influencing loan default within MFIs and FIs. In business characteristics, independent variables 
were regressed against the dependent variable separately for MFIs and FIs and their results shown in Tables 4.4 to 4.6 .

The regression results in Table 4.4 presented the $\mathrm{R}$ Square and adjusted $\mathrm{R}$ square. In MFIs independent variables produced Adjusted R Square was 0.643, which imply that the independent variables accounted for $64.3 \%$ variation in the dependent variable. In FIs, business characteristics produced an adjusted $\mathrm{R}$ square of 0.450 accounting for $45 \%$ of variation in loan default. This was slightly lower than MFIs whose variation was $64.3 \%$. This means that in FIs, $55 \%$ of the variables are unaccounted for in the model.

Table 4.4: Business Characteristics Model Summary

\begin{tabular}{|l|l|l|l|l|l|}
\hline & Model & R & R Square & Adjusted R Square & Std. Error of the Estimate \\
\hline MFIs & 1 & $.802^{\mathrm{a}}$ & .643 & .577 & 1.76386 \\
\hline FIs & 1 & $.452^{\mathrm{a}}$ & .204 & .450 & 0.880 \\
\hline
\end{tabular}

Table 4.5 presents the overall model after performing an $F$ test was significant with $F=9.728$ and $p$ value $=0.000$ which implies that independent variables strongly influence on loan default and FIs, F test was significant with a $\mathrm{p}$ value of 0.000 at $5 \%$ significance level $(\mathrm{P}<0.05)$ shows that the model was good in predicting loan default.

Table 4.1: Business Characteristics -ANOVA ${ }^{\mathrm{b}}$

\begin{tabular}{|l|l|l|l|l|l|}
\hline Model & Sum of Squares & df & F & Sig. \\
\hline \multirow{4}{*}{ MFIs } & Regression & 151.331 & 5 & 9.728 & $.000^{\mathrm{a}}$ \\
\cline { 2 - 6 } & Residual & 84.002 & 30 & & \\
\cline { 2 - 6 } & Total & 235.333 & 35 & & \\
\hline \multirow{4}{*}{ FIs } & Regression & 5.557 & 7 & 4.626 & $.000^{\mathrm{a}}$ \\
\cline { 2 - 6 } & Residual & 21.666 & 30 & & \\
\cline { 2 - 6 } & Total & 27.222 & 37 & & \\
\hline
\end{tabular}

Table 4.6 shows the variables that were statistically significant at 5\% significant level for both MFIs and FIs. In MFIs significant parameters were; BS-business size ( $\mathrm{p}=0.000)$, BE-borrower's experience in business $(p=0.022)$, BF-business portfolio $(p=0.010)$, FI- firm's industry $(p=0.037)$ and BL-business location $(p=0.020)$. MC- market competition $(p=0.041)$. Business operation period had a $p$ value of 0.356 therefore insignificant.In FIs, a t test indicated three significant variables whose $\mathrm{p}$ values were less than 0.05 namely; BSbusiness size $(p=0.015)$, BE-borrower's experience in business $(p=0.018)$ and MC-market competition $(p=$ 0.040). This confirms that loan default has some relationship with business size, borrower's experience in business and market competition.

Table4.2: Business Characteristics -Coefficients ${ }^{\mathrm{a}}$

\begin{tabular}{|c|c|c|c|c|c|c|c|c|c|c|c|}
\hline \multicolumn{2}{|c|}{ Model } & \multicolumn{4}{|c|}{$\begin{array}{l}\text { Unstandardized } \\
\text { Coefficients }\end{array}$} & \multicolumn{2}{|c|}{$\begin{array}{l}\text { Standardized } \\
\text { Coefficients }\end{array}$} & \multicolumn{2}{|l|}{$\mathrm{t}$} & \multicolumn{2}{|l|}{ Sig. } \\
\hline & & $\begin{array}{l}\text { MFIs } \\
\text { B }\end{array}$ & $\begin{array}{l}\text { FIs } \\
\text { B }\end{array}$ & $\begin{array}{l}\text { MFIs } \\
\text { Std. } \\
\text { Error }\end{array}$ & $\begin{array}{l}\text { FIs } \\
\text { Std. } \\
\text { Error }\end{array}$ & $\begin{array}{l}\text { MFIs } \\
\text { Beta }\end{array}$ & $\begin{array}{l}\text { FIs } \\
\text { Beta }\end{array}$ & MFIs & FIs & MFI & FIs \\
\hline \multirow[t]{8}{*}{1} & (Constant) & .281 & -2.294 & .672 & 1.994 & & & .419 & -.151 & .678 & .260 \\
\hline & Business size (BS) & 6.135 & 5.326 & .098 & .319 & .757 & .786 & 10.377 & 7.023 & .000 & .015 \\
\hline & $\begin{array}{l}\text { Borrower's experience } \\
\text { in business (BE) }\end{array}$ & 4.503 & .207 & .148 & .252 & .439 & .153 & 5.146 & .822 & .022 & .018 \\
\hline & Business' Portfolio(BF) & 5.062 & .385 & .077 & .265 & .515 & .753 & 9.801 & .522 & .010 & .450 \\
\hline & Firms' Industry(FI) & 3.085 & 0169 & .115 & .165 & 334 & .180 & 3.737 & .950 & .037 & .360 \\
\hline & Business Location (BL) & 4.327 & .162 & .136 & .275 & .437 & & 4.725 & & .020 & .560 \\
\hline & $\begin{array}{l}\text { Market Competition } \\
(\mathrm{MC})\end{array}$ & .136 & .138 & .176 & .184 & .152 & .187 & .754 & .751 & .041 & .040 \\
\hline & $\begin{array}{l}\text { Business Operation } \\
\text { Period (BOP) }\end{array}$ & .168 & .148 & .170 & .167 & .189 & .685 & .952 & .826 & .356 & .380 \\
\hline
\end{tabular}

A multiple regression model derived from individual co-efficient of these variables was generated as follows; Y $=0.281+0.6135 \mathrm{BS}+4.503 \mathrm{BE}+$ 5.062 BF + 3.085 FI + 4.327 BL + 0.136 MC in MFIs and in FIs; Y $=-\mathbf{2} .294+5.326 \mathrm{BS}+\mathbf{4} .207 \mathrm{BE}+\mathbf{0 . 1 3 8} \mathrm{MC}$. In summary, it is clear that there are more parameters causing loan default in business characteristics in MFI's than in FIs. In MFIs firm's industry, business location and business portfolio are significant while they are insignificant in FIs. It is evident from the findings in both MFIs and FIs that the overall model is statistically significant after $\mathrm{F}$ tests were performed. This implies that there exists some relationship between business characteristics and loan default within MFIs and FIs. From the two models generated $\mathrm{Y}=0.281+0.6135 \mathrm{BS}+4.503 \mathrm{BE}+5.062 \mathrm{BF}+3.085 \mathrm{FI}+4.327 \mathrm{BL}+0.136 \mathrm{MC}$ for 
MFIs and $\mathrm{Y}=-2.294+5.326 \mathrm{BS}+4.207 \mathrm{BE}+0.138 \mathrm{MC}$ for FIs none of the $\beta$ coefficients is equal to zero therefore we reject the Null hypothesis

\section{Discussions of Results}

Borrower's business experience was statistically significant in both MFIs and FIs as discussed in Section 4.2.9.4 on business characteristics. Experience in business gives the entrepreneur opportunities to seize in generating income as supported by Tundui and Tundui (2013) in Tanzania. Tundui and Tundui found out that experienced business people are likely to have less repayment problems. This concurs with Magali (2013) who pointed out that a borrower with some business experience accumulates skills that help him to manipulate business environments and hence able to prevent loan default. This is in line with Addo and Twum (2013) who argued that substantial business experience improves productivity and capital base which in return reduces the possibility of loan default. Pollio and Abuodie (2010) also suggested that increased business operation period decreases loan default by $28 \%$ since borrowers are able to increase productivity and consequently lowers default rate. Market competition is a major cause of loan default among FIs. This is supported by a study done by Ijaza et al., (2014) who suggested that recipients of government funds face stiff market competition as a result of selling homogeneous products that lack differentiation and diversification.

Business size is a key factor in influencing loan default both in MFIs and FIs. Credit officers' should consider the size of business in terms of stock and turnover before credit approval as this is important. This is consistent with Moti et al., (2012) who suggested that business size is an important predictor of loan default. Mashatola and Darroch (2003) in their study on loan status of sugarcane farmers in Kwazulu - Natal supports the finding in that business size and liquidity are major factors in determining loan repayment.

The type of activities a business engages in greatly determines the extent to which a loan is repaid. A study done in Tanzania (Magali, 2013) indicates that crop failure caused by rain shortages, deaths of the animals as a result of diseases led to high default rates to farmers who had loans. Udoh (2008) also argues that business failure as result of agricultural activities "increases the risk of portfolio default". Ledgerwood (1998) concurs with those findings and reported that agricultural businesses are risky due to fluctuations in production causing poor loan performance. Findings from Majeeb Pasha and Negese (2014) revealed that $75 \%$ of clients involved in non-agricultural businesses paid their loan better than those in agricultural businesses which contradict Proscovia (undated) who noted that there was no significant difference between trade and agriculture. This was affirmed by Munene and Guyo (2013) that businesses in manufacturing sector recorded the highest default cases, followed by service industry and agriculture and trade in that order. Sileshi et al., (2013) in their study in Ethiopia established that adequate rainfall in agro-ecological area reduces probability to default by 22.73 percent and increases rate of loan repayment by 12.69 percent. Technological advancement in Kenya is equally rendering some business outdated and obsolete and therefore one must keep abreast with the relevant technology.

The location of the business is positively related to loan payment as a favorably located business attracts more customers hence able to enhance loan effectiveness. This concurs with Proscovia (undated) in Uganda who argues that a favorable business location improves business sales and subsequently its profit and income.

\section{Summary of Levels and Units of Analysis}

The results presented in Table 4.7 outline the summary of the significant factors in both MFIs and FIs as per the findings. Some are common to both institutions and others are different.

Table 4.7: Summary of Levels and Units of Analysis

\begin{tabular}{|l|l|l|l|}
\hline Factor & Significant Parameters & Different Parameters in MFIs \&FIs \\
\hline & $\begin{array}{l}\text { Similar parameters } \\
\text { in MFIs \&FIs }\end{array}$ & MFIs & FIs \\
\hline $\begin{array}{l}\text { Business } \\
\text { characteristics }\end{array}$ & $\begin{array}{l}\text { Business size, } \\
\text { business experience } \\
\text { market competition }\end{array}$ & $\begin{array}{l}\text { Firm industry, } \\
\text { business portfolio }\end{array}$ & \\
\hline
\end{tabular}

\section{Summary, Conclusion And Recommendations}

The second objective of the study was to explore the influence of business characteristics on loan default in MFIs and FIs and therefore test the null hypothesis that stated; $\mathrm{H}_{02}$ : Business' characteristics are not significant in influencing loan default within MFIs and FIs. In business characteristics, independent variables were regressed against the dependent variable separately for MFIs and FIs. The regression results in MFIs produced indicated that the parameters measured accounted for $64.3 \%$ variation in the loan default while in 
those in FIs, accounted for $45 \%$ of variation in loan default. This therefore implied a positive relationship between business characteristics and loan default in both MFIs and FIs hence the null hypothesis was rejected. The results indicated that various variables were statistically significant at 5\% significant level for both MFIs and FIs while others were insignificant. In MFIs significant parameters were; BS-business size ( $p=0.000)$, BEborrower's experience in business $(p=0.022)$, BF-business portfolio $(p=0.010)$, FI- firm's industry $(p=0.037)$ and BL-business location $(\mathrm{p}=0.020)$. MC- market competition $(\mathrm{p}=0.041)$. A multiple regression model derived from individual co-efficient of these variables was generated as follows; $Y=\mathbf{0 . 2 8 1}+\mathbf{0 . 6 1 3 5} \mathbf{B S}+$ 4.503 BE + 5.062 BF + 3.085 FI + 4.327 BL + 0.136 MC. In FIs, a multiple regression model was generated for FIs as; $\mathrm{Y}=\mathbf{- 2 . 2 9 4}+\mathbf{5 . 3 2 6} \mathrm{BS}+\mathbf{4 . 2 0 7} \mathrm{BE}+\mathbf{0 . 1 3 8} \mathrm{MC}$ and three significant variables whose $\mathrm{p}$ values were less than 0.05 namely; BS-business size $(\mathrm{p}=0.015)$, BE-borrower's experience in business $(\mathrm{p}=$ $0.018)$ and MC-market competition $(\mathrm{p}=0.040)$. This confirms that loan default has some relationship with business size, borrower's experience in business and market competition. In summary, it is clear that there are more parameters causing loan default in business characteristics in MFI's than in FIs. In MFIs firm's industry, business location and business portfolio are significant while they are insignificant in FIs. Borrower's business experience was statistically significant in both MFIs and FIs. There is need to provide loans to MSEs that have been in operation for at least one year. Business operational period and the clients' experience in business are important factors to consider when disbursing loans. This acts as an assurance to the financial institution continuity for some time. The size of business and its location are important factors to consider when appraising loans and therefore there is dire need to physically visit the premises to assess business capability to repay loans.

\subsection{Areas for Further Research}

The researcher recommends the followings areas for further study that were not covered by this study:

i) Explore the impact of public entrepreneurial funds on MSEs

ii) There is need to do a comparative study on loan performance among MSEs that receive public funds and those receiving microcredit from MFIs.

iii) Examine the influence of the business characteristics in causing loan default commercial banks.

\section{References}

[1]. Abdullah A.M.,Wahab S.A., Malarvcizhi C.A \& Maviapums. (2011). Examining Critical Factors Affecting the Repayment of Microcredit. Amana Ikhtar Malaysia, International business Research, 4(2), 93 - 102.

[2]. Abid Jalah M. (2007). The Pecking order information, Asymmetry and Financial Market Efficiency, U.S.A., University of Minesota

[3]. ACCA (Association of Chartered Certified Accountants,(2011).The future of Microfinance in Kenya. ACCA Conference Report. Retrieved from http; /www.accaglobal.com/asf pdf

[4]. Acquah H. D. \& Addo J.(2011), Determinants of Loan Repayment Performance of Fisheries: Empirical Evidence from Ghana, Cercetare Agwmonmice in Moldova XLIV, (4) (148)/ 2014.

[5]. Addisu M. (2006).Microfinance Repayment Problems in the Informal Sector in Addis Ababa.Ethiopian Journal of Business and Development, 1(2), $115-119$.

[6]. Addo C. K.\& Twum S.B. (2013), sustainability of Microfinance in Developing Countries though come Credit Risk Management: Evidence from BusinessExperience, Purpose of Loan, Long Term, Profit Maximization Motive, Global Journal Finance and Banking Issues (7) $9-18$.

[7]. Adem O., Gichuhi A.W., \& Otieno R.O. (2012). Parametric Modeling of Probability of $\quad$ Bank $\quad$ Loan Default in Kenya. JAGST, 14(1), $61-74$.

[8]. Adoyo M. (2013). New Opportunities and Challenges for emerging Microfinance Models in the wake of Global Financial Crisis: A case of 'member - owned Microfinance Model' in Western Kenya; A paper presented to International JAK Seminar in Denmark 2013.

[9]. Aforabi J.A. (2010). Analysis of Loan Repayment among Small Scale Farmer in Oyo State, Nigeria, JournalofSocial Sciences, 22(2), $115-119$.

[10]. Agarwal S. \& Itzhak B.D. (2012), Do Loan Officers' Incentives Lead to Lax Lending Standards ? National University of Singapore

[11]. AMFIK (2013). Association of Microfinance Institutions of Kenya $\left(2^{\text {nd }} E d\right)$. Retrieved on $\quad 15.4 .2015$ from www.microfinancegateway.org/p/site/m/template/1.11.126321/ pdf.

[12]. $\quad$ AMFIK (2014). Association of Microfinance Institutions of Kenya $\left(2^{\text {nd }} \mathrm{Ed}\right)$

[13]. Amunyo-Vitor D.(2012), Determinants of loan Repayment Default among Farmers in $\quad$ Ghana, Journal of Development and Agricultural Economics 4(13)339-345

[14]. Anderson F. (2002), Taking a fresh look at Informal Finance, Fitchett eds; Informal Finance in Low Income Countries Boulder; Westview Press.

[15]. Anderson P. (2004), Does Experience matter in Lending? A Process Tracing Study on Experienced Loan Officers' and Novies' Decision Behavior, Journal of Economic Psychology, 25, 471-492

[16]. Antwi, Atta Mills E.F.E., Attamills G., \& Zhao X. (2008). Risk Factors of Loan Default Payment in Ghana: A case Study of Akuapem Rural Bank. International Journal of Academic Research in Accounting, Finance and Management Sciences, 2(4), $376-386$.

[17]. Appiah W. B. (2011). Factors Influencing Loan Delinquency in Small and Medium Enterprises in Ghana Commercial Bank Ltd. Kwame Nkrumah University of Science and Technology Institute of Distance Learning.

[18]. Asongo A.I.\& Idama A.(2014).The Causes of Loan Default in Microfinance Banks. The Experience of Standard Microfinance BankYola, Adamara State, Nigeria. ISOR Journal of Business and Management (ISOR-JBM), 16 (IV)74-81

[19]. Atieno R. (2001). Formal and Informal Institutions' Lending Policies and Access to Credit by Small-Scale Enterprises in Kenya: An empirical Assessment. African Economic Research Consortium, Nairobi. 
[20]. Ayogyam A., Godderna M.D, Mohammed H. \& Buateny E. (2013). Monitoring Loan Repayment among Farmers in Techiman, Ghana. Investigating the Effect of Cooperative Farming System, Journal of Emerging Trends in Economics and Management Scientists (JETEMS), 5(1),32 - 37

[21]. Guardian Nigeria (2009); News Wire : Nigeria High microfinance Interest Rates Causes ofLoanDefaults; http://www.microcapital.org/news-wireigeria- high microfinance interest rates causes of loan default. Retrieved on $21^{\text {th }}$ October .2015

[22]. Baibani S., Gilaninia S. \& Monabatkhah H. (2013). Assessment of Effective Factors on Non-Performing Loans (NPLs) Creations; Empirical Evidence from Iran (2006 -2011). Journal of Brazil and Applied Scientific Research 2(16), 10589 - 10597.

[23]. Beck T., Demirgic-Kunt, A. \& Peria M.S. (2008). Bank Financing for SMEs around the world, Drivers, Obstacles, Business Models and Lending Practices. The World Bank Development Research Group Finance and Private Sector Team

[24]. Ben Sultane Sultane B. (2008). Determinants of Successful Group Loan Repayment: An Application to Tunisia, Journal of Sustainable Development in Africa, 10(2), 66 -800.

[25]. Ben Sultane M (2007), The Promise of Microfinance for Poverty Relief in the Developing World, ]Proquest CSALLC, Discovery Guides

[26]. Bhattacherjee, A. (2012). Social Science Research Principles, Methods, and Practices. Text books Collection Book 3 Retrieved on Dec 16,2015 from

a. http://Scholarscommons.usf.edu/oa.textbooks

[27]. Bibi, A.(2006).Tanzania's Cooperative Look to the Future. Retrieved on 11.5.2015 from htpp://www.andrewbibby.com/pdfp Tanzania pdf.

[28]. Bichanga, W.O. \& Aseyo L. (2012). Causes of loan Default within Micro Finance Institutions in Kenya, International Journal of Contemporary Research in Business Vol 4(12) pp 316-335.

[29]. Biswas, S.BBC News, Medak, Andhra Padesh, 'India's Microfinance Suicide Epidemic' BBC, updated 16 Dec 2010. Retrieved from http://www.bbc.couk/news/world- SouthAsia - 11997571

[30]. Bryman A. (2003). Business Research Methods, Emma Bell, $2^{\text {nd }}$ Ed, Oxford University Press.

[31]. Buss T.F (2005), Microcredit in Sub-Saharan Africa a Symposium, International Studies- Washington ,7(1) 1 - 11

[32]. Carole L, Kimbarlin \& Winsterstein A.G (2008).Validity and Reliability of Measurement Instruments used in Research, AM J Heath System Pham , $65 ; 276-284$

[33]. Carter S., Shew E, Lam W. \& Wilson (2007). Gender; Entrepreneurship, and Bank Lending: The criteria and Processes used by Bank Loan Officers in Accessing Applications. Baylor University.

[34]. CGAP (1999). Measuring credit Delinquency: Occasional Paper No. 3 CGAP Secretariat 1818h Street.

[35]. CGAP (2004). Key Principles of Microfinance. Building Financial Systems for the Poor, 1818 H Street

[36]. CGAP (2010). Andra Pradesh 2010, Global Implications of the crisis in Indian Microfinance, GGAP focus note No. 67 (Nor) 1 8 .

[37]. CGAP (2013). Managing fueling Deposit taking Institutions: Regulatory Experience from Africa, Focus Note 88168

[38]. Chanji T. (2016). Coast High default, late payments rates hit Uwezo fund loans.Retrieved 15.10 .2016 http://www.standard media.co.ke/article/2000214398/high.default.late.payment.rates.hit.uwezo-fund-loans

[39]. Chen J.J.(2004). Determinants of Capital Structure of Chinese-Listed Companies. Journal of Business Research, Issue 57, 1341 1351.

[40]. Chen M. \& Mahmud S. (1995). Assessing change in Women's Lives: A conceptual Framework, working Paper No. 2, BRAC ICDDR, B Joint Research Project at Matlab.

[41]. Chirwa, E.A. (1997), An econometric Analysis of the determinants of Agricultural credit payment in Malawi, African Review of Money Finance and Banking, roll 1-2, $\quad 107 \quad-122$

[42]. Chowdbury A (2009). Microfinance as a poverty reduction tool; A critical Assessment, DESA Working Paper No. 89, 1 - 10.

[43]. Cios.org (2015), Chapter 9; Distributions: Population, Sample and Sampling Distributions, Retrieved on Dec16, 2015 from http://www,cios,org/redbook/rmcs/ch09pdf

[44]. Cochran L. (1997). Sampling Techniques, (3rd Ed.). New York: John Wisey \&Sons Inc.

[45]. Consultative Group (OGAP), Key Principles of Microfinance. Retrieved from http://arabic.microfinancegateway.org/section/key principles/ July, 16,2014

[46]. Crabb, P.R. \& Keller, T. (2006). A Test of Portfolio Risk in Microfinance Institutions. Faith \& Economics - 47/48 25 - 39.

[47]. Creswell, J.W. (2014) Resign design, Qualitative, Quantitive and mixed methods approaches, New Delhi, SAGE Publishers ltd.

[48]. CSFI (Centre for the Study of Financial Innovation). (2011). Microfinance Banana Skins 2011;Retrievedfrom http://www.cgap.org/gm . July, 16,2014http://accromnm.org/pdf/creditscoring.

[49]. Dadzie et al., (2012).The Effects of Loan Defaults on the Operations of Microfinance Institutions (MFIs) (A case study of Sinapi Aba Trust-Ashanti Region), A thesis paper presented to Christian Service University College.

[50]. Dudovisky, John (2013). An Ultimate Guide to Writing a Dissertation in Business Studies: A Step-by Step Assistance. Available at: http://research-methodology.net/about-us/ebook/

[51]. EIU (Economist Intelligence Unit) (2010). Global Miscroscope on the Microfinance Business Environment, Retrieved from http://graphics, elu.com/upload/eb/EIV - Global - Microscope - 2010 -Eng-WEB.pdf.

[52]. Etzensperger C., (2014). Microfinance Market Outlook 2014, No "Sudden Stop" demand for Microfinance Soars , responsibility.

[53]. Explorable.com (2009), Research Population, Retrieved Dec 10, 2015. https://explorable.com/research-population

[54]. Fararo, T. J., \& Doreian, P. (1998). The Theory of Solidarity: An Agenda of Problems. In:.Amsterdam: Gordon and Breach Publishers

[55]. Farhodora L. Kimani E., Masa R., Deng M., \& Mungai K (2008). Commonly Driven Development andMicrofinance, Development Practice in International Settings, George Warren Brown School of Social Work.

[56]. Field, A. (2000). Discovering statistics using SPSS for Windows. London- Thousand Oaks-New Delhi; Sage Publications.

[57]. Field, E. \& Pande R. (2008). Repayment frequency and default performance in community. Micro-finance; Evidence from India. Journal of the European Economic Association, 6(2-3), 501 - 509

[58]. Frank, M., \& Goyal, vik (2009), Capital Structure Accessions, which factors are Reliably Important? Financial Management, 38(I) $1-37$

[59]. FSD (Financial Sector Deeping), Kenya. (2009). Fin Access National Survey 2009; Dynamics of Financial Landscape, Report.Retrieved from http://www.fsdkenya.org/finances/documents/09-06-10

[60]. Gatimu, Maina E.,\& Kalui F.M. (2014. Assessing Institutional Factors Contributing to Loan Kenya'schallenging Institutions in Kenya, IOSR Journal of Humanities and Social Sciences, 19(5) 105-123.

[61]. George O.K. (2008). The Role of Micro Finance in Fostering Women Entrepreneurship

in Kenya. 
[63]. Gitau N.M. \& Wanyoike D.M. (2014). Influence of Kenya industrial Estates Services to the Growth of Micro and Small Enterprises in Kenya. International Journal of Arts and Commerce 3(3)81-88

[64]. Global Entrepreneurship Monitor (GEM)(n.d). Women and Entrepreneurship, Centre for Women's Leadership, Banson College, MA, U.S.A.

[65]. Godquin M. (2004). Microfinance Repayment Performance In Bangladesh: How To Improve .The Allocation of Loans By MFIs, World Development, 32(11), 1909 - 1926.

[66]. Goetz A.M. \& San Gupta R. (1996). Who Takes the Credit? Gender, Power and Control over Loan .use in Rural Credit Program in Bangladesh.World Development 24(1). Pp $45-\quad 64$.

[67]. Gomez, R. \& Santor, E. (2008). Does the Microfinance Lending Model Actually Work? The White Journal of Diplomacy and International Relations 37-55

[68]. Hair J. Anderson R.E, Tatham R.L \& Black W,C(1995), Multivariate Data Analysis ,

New Jersey, Prentice -Hall Inc.

[69]. Hall, C. (2003). The SME Policy Framework in ASEAN and APEC: Ben Sultane chmark comparison and Analysis.16 Annual Conference of Small Enterprise Association of Australia and New Zealand.

[70]. Halvoet, N. (2006). The Differential Impact on Gender Relations Of 'Transformatory' and 'Instrumentalist' Women Group Intermediation in Microfinance Schemes: A case study for rural South India. Journal of International Women studies, 7(4) $36-50$

[71]. Hauges, S.(1999). Household, Group and Program Factors in Group Based Credit Deliquency, Department of Economics, Ripon College

[72]. Hechter, M. (1987). Principles of Group Solidarity, Berkeley, CA: University of California Press.

[73]. Herrera F. (2003).Performance Indicators for Microfinance Institutions, Technical Guide (3 ${ }^{\text {rd }}$ Ed.), Washington DC.

[74]. Hinkle D.E.,Wiersma W.and Jurs S. G.(2003) Applied Sciences for Behavioural sciences( $5^{\text {th }}$ Ed), Boston, Mass: Houghton Mifflin

[75]. Holt, S. (1991). Village Banking: A Cross Country study of a Community - Based Lending methodology GEMINI working paper No 25, New York: PACT Publication.

[76]. Hulme D, Mosley P (1996) Finance against poverty. London: Routledge

[77]. Ijaza A.K, Mwangi S.W. of Ngetich K.A. (2014) Challenges faced by the women Enterprise Fund in Kenya. A Survey of Hamisi Constituency Vihiga County -Kenya. Research on Humanities and Social Sciences 4(14) $10-23$

[78]. Jibran S., Wajid S.A, Waheed I, \& Mohammed T.M. (2012). Pecking at Pecking Order Theory: Evidence from Pakistan's Non-financial Sector. Journal of Competitiveness 4(4), $86-95$

[79]. Kabeer N. (1999), the conditions and Consequences of choice; Reflections on the Measurement of Women's Empowerment, UNRISD Discussion Paper DP108 General: United Nations Research Institute for Social Development.

[80]. Kadongo O, Kendi L.G (2013). Individual Lending versus Group Lending: An Evaluation with Kenya's Microfinance Data.

[81]. Kamanza R. M. (2014), Causes of Default on Micro-credit among women Micro Entrepreneurs in Kenya. A Case Study of Women Enterprise Development Fund (WEDF) Msambweni Constituency; 105R Journal of Economics and Finance (105R - JEF) 3(6) $32-47$.

[82]. Kamanza R.M. (2014),Causes of Default on Micro-credit among Women Entrepreneurs in Kenya. Access of study of Women Enterprise Development Fund (WEDF) Msabweni Constituency; 105R Journal of Economics and Finance (105R - JEF), 3(6), 32-47.

[83]. Kariuki J.N.(2010). Effective collection Policy. Nairobi: KASNEB Publishers.

[84]. Kathuri N. J. \& Pals A.D. (1993). Introduction to Educational Research, Egerton: University Education Book Series

[85]. KIPPRA ( Kenya Institute of Public Policy and Research ) (2010), Kenya Economic Report , Nairobi

[86]. Kiraka R.N.,Kobia M.\& Katwalo A.M.(2013), Micro ,Small and Medium Enterprises Growth and Innovation in Kenya: A case study on the women enterprises fund , ICBE

[87]. KarlanD.S\&Morduch.J.(2009).AccesstoFinance.Availableat: http://karlan.yale.edu/p/HDE_June_11_2009_Access_to_Finance.pdf

[88]. Korankye A.A.(2014).Causes and Control Loan Default/Delinquency in Microfinance Institutions in Ghana , American International Journal of Contemporary Research 4(12) 36-45.

[89]. Kothari C.R (2004).Research Methodology: Methods and Techniques (2 ${ }^{\text {nd }}$ Ed.), Delhi: New Age International (P) Ltd Publishers.

[90]. Landman, T. 2008. Issues and methods in comparative politics: an introduction; 3rd ed.

[91]. Langat C., Marn L., Chekwony J., \& Kotut S.C. (2012). Youth Enterprise Development 182.

[92]. Ledesma R.D \& Valero-Mora P.(2007), Determining the Number of Factors to Retain in EFA:an easy-to-use Computer Program for Carrying out Parallel Analysis. Practical Assessment, Research \& Evaluation, 12( 2).

[93]. Ledgerwood, J. (1998) Microfinance Handbook: An Institutional and Financial Perspective. Washington DC: World Bank. USA (c) World Bank Publicationshttps://openknowledge.wordbank.org/handle.10986/12383 License: CC BY 3.0 IGO

[94]. Levin G. (2012). Critique of Microcredit as a Development Model Pursuit, The Journal ofUnderground Research at the University of Tennessee 4(1) $109-117$.

[95]. Liedholm, D. \& Mead D. (2005). Small Enterprises and Economic Development: London, RoutledgeLondon, New York: Routledge.

[96]. Lor, P. (2011): International and Comparative Librarianship, Chapter 4 draft 2011-04-20

[97]. Luigi P. and Povin V. (undated) A Review of the Capital Structure Theories, pp 315-320

[98]. Machira H.K., Njato I.C, Thiane K.S. \& Kinyo H.S.(2014)., Accessibility of Women Enterprises Fund among Small and Micro Women Enterprises in Tharaka South District , Kenya , Journal of Business and Management 16 (1) 79-103

[99]. Magali J.J. (2013). Factors Affecting Credit Default Risks for Rural Savings and credit cooperative Societies (SACCOs) in Tanzania, European Journal of Business and Management, 5(32) 60 -73.

[100]. Maghimbi, S. (2010). Cooperatives in Tanzania Mainland: Revival and Growth. Coop Africa Working Paper No. 14 Series on the status of cooperative Development in Africa: ILO office in Dare Salam, Tanzania.

[101]. Mahajan V. (2005). From Microcredit to Livelihood Finance, Economic and Political weekly

[102]. Mahmud S. (2003). Actually how Empowering is Microcredit? Development and Change, $34(4) 577-605$.

[103]. Mashotola M.C. \& Darroch M.A.G. (2003),Factors Affecting the Loan status of Sugarcane Farmers using a graduated Mortgage Loan Repayment scheme in Kwazulu - Natal. Agrekon 42(4) 353 - 365. 
[104]. Mayoux L.(1999). Questioning Virtuous Spirals; Micro finance and Women's Empowerment in Africa, Journal of International Development 1(7) $957-1054$

[105]. Microfinance Information Exchange, Inc. (2009-12-01). "MicroBanking Bulletin Issue \#19, December, 2009, pp. 49". Microfinance Information Exchange, Inc.

[106]. Migiro, O (2005). Small and Medium Scale Manufacturing Enterprises in Kenya: A perspective on alternative sources of financing, Retrieved from http://hide.handle.net/10530/1170.

[107]. Million, S., Nyikal, R., \& Wania, S. (2012). Factors affecting loan repayment performance. Developing Countries Studies, 2(11), 4-10

[108]. Mix (Microfinance Informance Exchange and CGAP (Consultative Group to Assist the Poor) (2010), Sub-Saharan Africa 2009

[109]. Mix Microfinance World; Sub-Saharan Africa Microfinance Analysis and Report 2010. A report from microfinance Information Exchange (Mix) and Consultative Group to Assist the poor (CGAP).

[110]. Mokhtar S.H., Nartea G.,\& Gan C. (2012). Determinants of Microcredit Loans Repayment Problem among Microfinance Borrowers in Malaysia, International Journal of business and Social Research (USRR), 2, $33-45$

[111]. Moti H.O, Masinde J.S, Mugenda N.G \& Sindani M.N(2012), Effectiveness of credit Management System on Loan Performance; Empirical Evidence from Microfinance Sector in Kenya, International Journal of Business, Humanities and Technology 2(6) $99 \quad-108$

[112]. Mugenda O.M \&Mugenda A. G (1999) Research Methods: Quantitative and Qualitative Approaches (2 ${ }^{\text {nd }}$ Ed.), Nairobi, Laba Graphics Services Ltd.

[113]. Munene H.N. \& Guyo S.H.(2013). Factors Influencing Loan Repayment Default in Micro Finance Institutions: The Experience of Imenti North District, Kenya . International Journal of applied Science and Technology 3(3)80-84

[114]. Murathi A. \& Weda J. O. (2015), critical factors in Repayment of Constituency Youth EnterpriseScheme in Kirinyaga Central District, Kenya, Journal of Finance and Accounting 3(2) $19-27$.

[115]. Mwaniki R. (2006), Supporting SMEs Development and Role of Microfinance in Africa, IWAFI Africa Trust

[116]. Myers S. C. and Majhuf N.S (1984). Corporate Financing and Investment Discussions when Firms have Information that Investment do not have, Journal of Financial Economics (13) 187-221,Nations, New York.

[117]. Nawai N.B. \& Mohd Shariff M.N.B. (2013), Determinants of Repayment Performance in microfinance programs in Malysia, Laban Buttetin of International Business and Finance 11, 2013, $14-288$

[118]. NBE (National Bank of Ethiopia) (2010). Annual Report of 2008/2009, Addis Ababa, Ethiopia

[119]. Ngahu S.T. \& Wagoki A.J. (2014). Effect of Group Lending on Management of Loan Default Rates mong Microfinance Institutions in Nakuru Town, Kenya, International Journal of science and Research (IJSL) 3(3), 606 - 609

[120]. Ngehveru C.B.,\&Nembu F.Z.(2010). The Impact of MFIs in the Development of SMES inCameroon, Environmental Economic Management, Degree Thesis No 601,ISSN 1401-4084. Uppasah,2010.

[121]. Njoka J.E \& Odii M.A.C.A (1991), Determinants of Loan Repayment under the Special Emergency Loan Schemes (SEALS) in Nigeria. A case study of Imo State, Africa Review of money Finance and Banking Vol (1) 31-52

[122]. Oduor P. \% Obi L. (2016), Hard Economic Times Dampen Christmas Cheers for Families, Daily Nation ,December 24,2016

[123]. Oke J, Adeyemo R.,\& Agonlahor M.(2007). An empirical Analysis of Microcredit repayment in South-Western Nigeria, Humanity and Social Sciences Journal (20) (1) 63-74

[124]. Okorie A.(2004), Major Determinants of Agricultural Small Holders Loan Repayment In DevelopingEconomy:Empirical Evidence From Ondo State, Nigeria. The Journal of Socio-Economics 21(4), 223 - 234

[125]. Olagunju F.I.\& Adeyemo R.(2007), Determinants Decision among Small Holder Farmers in Southwestern Nigeria, Paskistan Journal of Social Sciences 4(5): 677-686

[126]. Oni, T.K (1999), 'Bank Credit Facilities for Small Holder Farmers; Implications for Food Security in Nigeria.' Poverty Alteration and Food Security in Nigeria, Ibadan, NAAE, PP342-348

[127]. Onyeagocha S.U.O, Chidevele S.A.N.D, Okorji E.C, Ada-Henri UkohaOsuji M.N. \& Korie D.C 2012). Determinants of Loan Repayment of Microfinance Institutions in Southeast states of Nigeria.International Journal of social sciences and humanities 1(1) 4- 9

[128]. Orrick, Herrington and Sutcliffe (2012), Microfinance, Advocates for International Development

[129]. Oso W.Y. \& Osen D. (2009). A General Guide to Writing Research Proposal and Writing and Report, a Handbook For Beginners. Nairobi: Jomo Kenyatta Foundation

[130]. Pachico E. (2009) "No Pago" Confronts Microfinance in Nicaragua, nacla North America Congress on Latin America, Knowledge Knowsx no Boarders.

[131]. Polio G., \& Obuobie J. (2010). Microfinance Default Rates in Ghana: Evidence from Individual - Liability Credit Contracts. Feature Articles, Micro Bulletin: Issue 20, September2010

[132]. Pollin R. (2007), Microproduct, "False Hopes and Real Possibilities" Foreign Policy Focus, Retrieved from http//fpdif.org/fpiftxt/4323.

[133]. Pretes M (2002), Micro Equity and Microfinance, World Development 30 (8) 1341 - 1353

[134]. Proscovia N. (undated), Determinants of effectiveness of Microfinance Institutions (MFI) Loans among Selected Small Business in Kampala and Mpigi Districts, An MBAThesis submitted to Makerere University

[135]. Ragin, C.C. (1987). The comparative method: moving beyond qualitative and quantitative

[136]. Rai S. (2011). India the Death of Microfinance. Global Post $9^{\text {th }}$ January 2011; http://www.globalpost.com/dispatch/india/110106/microfinance-grameen-micro- $\quad$ loans- $\begin{gathered}9 \\ \text { andraha Pradesh. Retrived }\end{gathered}$ on $24^{\text {th }}$ May 2011

[137]. Ralton D.,(2003). International Journal of Bank Marketing, Lending Practices and the Viability - Social Objectives Conflict in Credit Unions Publishers, MCB UP Ltd.

[138]. Reinecke,G. (2002). Small Enterprises, Big Challenges A Literature Review on the Impact of Policy Environment on the Creation and Improvement of Jobs within Small Enterprises Geneva : ILO

[139]. Reservie Bank of Zimbabwe (2012), The Operations of Microfinance Institutions in Zimbabwe.]Retrieved on 11.5.2015 from www.rbx.co.zW

[140]. Robert A. (2006). Empowerment Participation and Social Work: New York; Palgrave Macmillan

[141]. Robinson M. (2002). The Microfinance Revolution, Sustainable Finance for the Poor. The World Bank, Washington Dc

[142]. RoK (2005), Sessional Paper of 2005 on Development of Micro and Small Enterprises for Wealth Creation, Employment Generation and Poverty Reduction, Nairobi: Government Printers.

[143]. RoK (2010), Draft Sessional Paper on YEDF

[144]. RoK (2011), Economic Survey; Kenya Bureau of Statistics, government Printer, Nairobi 
[145]. RoK (2013), Economic Survey; Kenya Bureau of Statistics, Government Printer,Nairobi Retrieved21.10.2015from http://www.uneca.ort/dpm/sme\%20strategic\%20frameworkpdf.

[146]. Roodman D. and Qureshi(U.(2006), Microfinance as Business Center for Global Development, Washington DC

[147]. Roslan, A.H. and Zain M, A.K.(2009), Determinants of Microcredit Repayment in Malysia: the case of Agrobank, Humanity and Social schemes Journal 4(1) $45-52$

[148]. Rummel R. J (1970), Applied Factor Analysis, Evaston, I.L ; Northwestern University Press

[149]. Samuel; P. (2015), Advice on Reliability Analysis with Small Samples, Birmingham City University,Centre for Academic Success

[150]. Sangoro O, Ochieng P, and Buretti P.(2012), Determinants of Loan Repayment among the Women-Owned Enterprise In Kenya. A case of Eldoret Municipality, Lambert Academic Publishing A.G. and C.K.G

[151]. Schreiner, M. (2000). Formal ROSCAS in Argentina, Development in Practical, 10(2) $229-232$.

[152]. Schurmann A.T. \& Johnston H.B (2009), The Group Lending Model and Social Closure: Microcredit, Exclusion, and Health in Bangladeshi, J. Health Popul Nutr 27(4): 518 -527.morris G. and Barnes C. (1999), An Assessment of the Impact of $\backslash$ Microfinance: A case study of Uganda, Journal of Microfinance 7(1) $39-54$

[153]. Sharma M .\&Zeller N, (2000), Many Borrow, Mode Save, and All Insure: Implications for food, Microfinance Policy, 25, 143 $-167$

[154]. Shukran K. \& Rahman (2011), A Grameen Bank Concept: Microcredit and Poverty Alleviation Program in Bangladesh, International Conference on emerging Trends in Computer and Image Processing (ICETCIP'2011) Bangkok

[155]. Shyam-Sunder, L.\&Myers, S.C. (1999). Testing Static Trade off against Pecking order models of capital structure Journal of Financial Economics, 51(2) 219-224.

[156]. Sileshi M., Nyikal R. \& Wangia S. (2012). Factors Affecting Loan Repayment Reinfomance of Small Holder Farmers in East Havarghe, Ethiopia, Developing Country Studies 2(11) $205-213$

[157]. Sjomsoeddin I.M. (2010), Does Micro Credit Really Help the Poor? September 2011 pdf Retrieved on May 11,2014

[158]. Smilor,R.W.(1987).Manging the Incubator Systems Critical Success Factors to Accelreate New CompNY Development, IEEE Transitions Engineering 4(3) 146-156

[159]. Srinivasan R. (2007). Measuring Delinquency and Default in Microfinance Institutions, Working Paper No. 254: Indian Institute of Management Bangalore pp $1-13$.

[160]. Sterns K (1991), controlling Delinquency, GEMINI Technical Note No. 1, April 1991, p \& f.

[161]. Tarakol M.\& Dennich R. (2011), Making Sense of Cronbach’ Alpha ,International Journal of Medical Education, 2, 53-55

[162]. Stiglitz J \& Weiss A (2007), Credit Rationing in Markets with Imperfect Information; American Economic Review, 71 (3): 393 - 410 Strategies. Berkeley (CA): University of California Press.

[163]. Tedeschi A. (2006), Here Today, Gone Tomorrow; Can Dynamics Incentive Make Microfinance Move Flexible? Journal of Development Economics 80(1) 84 - 105

[164]. Tundui C. \&Tundui H.(2013).Microcredit, Micro Enterprising and Repayment Myth: the Case of Micro and Small Women Business Entrepreneurs In Tanzania. American Journal of Business and Management 2(1), 20 - 30.

[165]. Udoh E.J (2008), Estimation of Loan Default among Ben Sultane eficiaries of State Government Owned Agricultural Loan Scheme, Nigeria. Journal of Central European Agriculture 9(2) 343 - 352.

[166]. UNEP (2007). Innovative Financing for Sustainable Small and Medium Enterprises in Africa,International workshops, Geneva, Switzerland, Meeting Report

[167]. United Nations (2006), Building Inclusive Financial Sector for Development. United

[168]. United Nations (2011), Draft -Microfinance in Africa;Overview andSuggestions for Stakeholders,September,http//www.un.org/Africa\%20Draft\%20Report\%20

[169]. United Nations, (2007), World Youths Report 2007: Youth PEOPLES Transition to Adulthood: Progress and Challenges, "New York: United states

[170]. Wanambisi A.N., \& Bwisa H.M. (2013), Effects of Microfinance Lending on Business Performance: A Survey of Micro and Small Enterprises in Kitale Municipality Kenya. International Journal of Academic Research in Business and Social Services 3(17) $56-67$

[171]. Wang W. \& Zhoux (2011), Could Financil Indicators Predict the Default of Small and Medium -Sized Enterprises? Evidence from Chinese Small and Medium Sized Enterprises, International Journal of Conference Economic and Finance Research IPEDR 4(2011) 72-76

[172]. Warue B.N. (2012), Factors Affecting Loan Delinquency in Microfinance Institutions in Kenya,International Journal of management sciences and Business Research 1 (12), 27 - 48.

[173]. Warwick, D.P.\& Lininger, C.A(1995). The Sample Survey Theory: Theory Practice,MCGraw Hill; New York

[174]. Weele, K. V. \& Markowich (2001).Managing High and Hyper Inflation in Microfinance: Opportunity International's Experience in Bulgaria and Russia USAID - Microenterprise Best Practice (MBP) Project August.

[175]. Wikipedia (2014), Retrieved from http:/en.wikipidea.org/wiki/empowerment, on November,

[176]. Wikipedia(2014) Retrieved from http://en.wikipedia.org/wiki/Microcredit on November,26,2014.

[177]. Women Enterprise Fund (2014), Empowering Women for Entrepreneurs for Socio-Economic Development :Retrieved from http:/ www.wef.co.ke.

[178]. Wool Cook, M. (2008). Micro Enterprises and Social Capital; A framework for theory, Research and Policy Journal of Social Economics, 30, $193-198$

[179]. World Bank (2006). Provision of Financial Services to the rural People. What can be done when services are not available? Washington D.C. World Bank.

[180]. World Education Australia (2006), Principles of Sustainable Microfinance, pp 1-4 updated Sep 06.

[181]. Wrenn E. (2005), Microfinance Literature Review.

[182]. Yaqub, S. (1995). Empowered to Default? Evidence from BRAC's Micro Credit Programmes, Small Enterprise Development $6(4), 4-13$

[183]. Yegon J.C, Kiptemboi J, Kemboi J.K. and Chelimo K.K, (2013), Determinants of a State Owned Agricultural Loan Scheme in Uasin Gishu County, Kenya, Journal of Emerging Trends in Economics and Management Sciences Vol 5(1) pp 51 - 55

[184]. Yunus, M. (2003). Barrier to the Poor; Micro Lending and the Battle against World Poverty, Public Affairs, New York.

[185]. Zeller M. (1998). Determinants of Repayment Performance in Credit Groups: The role of Program , Intragroup Risk Pooling and Social Cohesion, Economic Development and Cultural Change 46(3)599-621

[186]. Zikmund W.G, Babin B. J, Carr J.C. and Griffin M.(2013).Business Research Methods, South Western ,Cengage Learning. 